\title{
The 2011 eruption of Nabro volcano, Eritrea: perspectives on magmatic processes from melt inclusions
}

\author{
Amy Donovan ${ }^{1,3} \cdot$ Jon Blundy $^{2} \cdot$ Clive Oppenheimer $^{3} \cdot$ Iris Buisman $^{4}$
}

Received: 22 February 2017 / Accepted: 14 November 2017 / Published online: 27 November 2017

(C) The Author(s) 2017. This article is an open access publication

\begin{abstract}
The 2011 eruption of Nabro volcano, Eritrea, produced one of the largest volcanic sulphur inputs to the atmosphere since the 1991 eruption of Mt. Pinatubo, yet has received comparatively little scientific attention. Nabro forms part of an off-axis alignment, broadly perpendicular to the Afar Rift, and has a history of large-magnitude explosive silicic eruptions, as well as smaller more mafic ones. Here, we present and analyse extensive petrological data obtained from samples of trachybasaltic tephra erupted during the 2011 eruption to assess the pre-eruptive magma storage system and explain the large sulphur emission. We show that the eruption involved two texturally distinct batches of magma, one of which was more primitive and richer in sulphur than the other, which was higher in water (up to $2.5 \mathrm{wt} \%$ ). Modelling of the degassing and crystallisation histories demonstrates that the more primitive magma rose rapidly from depth and experienced degassing crystallisation, while the other experienced isobaric cooling in the crust at around $5 \mathrm{~km}$ depth. Interaction between the two batches occurred shortly before the eruption. The eruption itself was likely triggered by recharge-induced destabilisation of vertically extensive mush zone under the volcano. This could potentially account for the large volume of sulphur released. Some of the melt inclusions are volatile undersaturated, and suggest that the original water content of the magma was around $1.3 \mathrm{wt} \%$, which is relatively high for an intraplate setting, but consistent with seismic studies of the Afar plume. This eruption was smaller than some geological eruptions at Nabro, but provides important insights into the plumbing systems and dynamics of off-axis volcanoes in Afar.
\end{abstract}

Keywords Melt inclusions $\cdot$ Afar volcanism $\cdot$ Magmatic processes $\cdot$ Nabro volcano

Communicated by Timothy L. Grove.

Electronic supplementary material The online version of this article (https://doi.org/10.1007/s00410-017-1425-2) contains supplementary material, which is available to authorized users.

Amy Donovan

amy.donovan@kcl.ac.uk

1 Department of Geography, King's College London, London, UK

2 School of Earth Sciences, University of Bristol, Bristol BS8 1RJ, UK

3 Department of Geography, University of Cambridge, Cambridge, UK

4 Department of Earth Sciences, University of Cambridge, Cambridge, UK

\section{Introduction}

Nabro volcano in the northern Afar Depression, Eritrea, is a stratovolcano with a breached caldera opening to the southwest. It is the highest topographical feature in the region, and abuts the caldera of Mallahle volcano at the international border with Ethiopia (Fig. 1), forming part of an alignment known as the Bidu Massif. The volcano was little heard of until 2011 when it was the site of a substantial explosive and effusive eruption - the first in recorded history-that precipitated a significant humanitarian crisis, disrupted aviation and yielded one of the largest sulphur inputs to the atmosphere since the 1991 eruption of Mount Pinatubo (Goitom et al. 2015; Theys et al. 2013). Here, we present the first detailed petrological and geochemical study of the eruptive products, focusing on the tephra deposits. Our aims are to characterise the magma(s) involved in the eruption, evaluate trigger mechanisms, define degassing mechanisms and trajectories, and understand the high sulphur yield. 

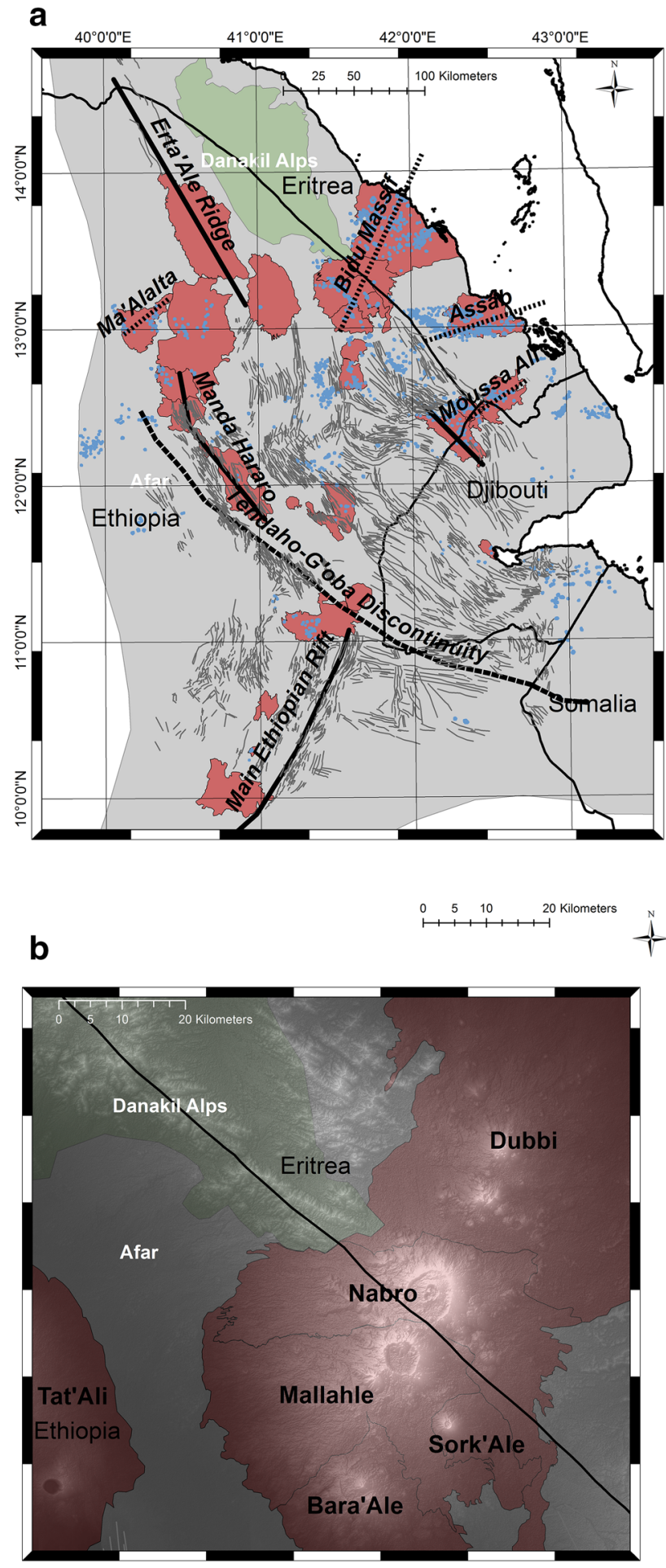

Fig. 1 a Map of the Afar Depression, showing the tectonic structures and main volcanic fields discussed in this paper. Redrawn from Barberi and Varet (1977), using Landsat 8 imagery. Dark red areas are the main volcanic fields. Thin black lines are faults and linear structures; thick black lines are spreading centres; short-dashed lines are the marginal ranges after Barberi et al. 1974a; and the long-dashed line is the Tendaho-G'oba Discontinuity. The Danakil Alps (part of the Danakil Horst) are shown in light green. Small blue dots are spatter cones. Note the NW-SE arrangement of spatter cones to the south of Mallahle, perpendicular to the Bidu alignment. b Close-up of Nabro volcano (colour scheme as for a), using a digital elevation model (ASTER GDEM generated by METI and NASA) to highlight the calderas

\section{Regional background}

The Afar Depression is an active spreading zone at the boundary between the Arabian and Nubian plates, lying just to the west of the triple junction with the Somalian plate (Fig. 1). Eruption of the flood basalts of the Ethiopian Traps circa 30 Ma ago (Courtillot et al. 1999; Schilling 1973) presaged the separation of Arabia and Africa and formation of the Afar Rift (Furman et al. 2006; Hofmann et al. 1997). Most lavas now exposed in the Afar Depression are much younger than the Traps and record the transition to oceanfloor magmatism over the past $10 \mathrm{Ma}$ (Barrat et al. 2003; Hagos et al. 2016).

Despite the logistical challenges of carrying out fieldwork in Afar, several decades of research underpin our current understanding of the regional volcanism and rifting (Ayele et al. 2007, 2009; Barberi et al. 1974a, b; Ferguson et al. 2010; Field et al. 2012a, b, 2013; Hammond et al. 2013, 2011; Keir et al. 2013, 2011; Lahitte et al. 2003). Expeditions in the 1970s documented Afar volcanism at reconnaissance scale (Barberi et al. 1974a, b, 1970; Civetta et al. 1975). Barberi et al. (1970) distinguished between the axial ranges (Erta'Ale and Alayta) and marginal ranges exemplified by Ma'Alalta and Dabbahu (Field et al. 2012b, 2013; Wiart and Oppenheimer 2005). The latter are generally more alkaline and show signs of crustal contamination (Civetta et al. 1975; De Fino et al. 1978; Ottonello et al. 1978). Barberi et al. (1974a) went on to describe the marginal ranges as "transverse" ranges, drawing an analogy with those that offset the Mid Atlantic Ridge, an idea that has not been universally accepted. De Fino et al. (1978), for example, attributed the difference in composition between the marginal and axial ranges to differing redox conditions, possibly controlled by mantle temperature variations. Conversely, Civetta et al. (1975) argued for structural control on the depth of mantle melting.

More recent studies of the Afar region and Ethiopian Rift Valley have revealed physical and chemical heterogeneity [e.g., (Ebinger et al. 2010; Ebinger and Sleep 1998; Furman et al. 2006; Keir et al. 2011; Pik et al. 2008, 2006) Rooney et al. 2012a]; Hammond et al. (2011) showed that there is a considerable variation in Moho depth across Afar, even within the central rift area. Their study area does not quite reach the Bidu Massif, but points to a crust thickness of about $20 \mathrm{~km}$ in the region of the Danakil Horst (Fig. 1). Hammond et al. (2013) inferred from seismic data that several diapiric mantle upwellings are present under off-axis volcanoes, including Nabro. They suggested that these might arise from elevated $\mathrm{H}_{2} \mathrm{O}$ contents and enhanced melting along the edges of thicker continental lithosphere. Volcanism across the Red Sea in Yemen, likely related to the Afar melting anomaly [e.g., (Baker et al. 1998; Ukstins et al. 
2002)] shows evidence of elevated $\mathrm{H}_{2} \mathrm{O}$ content (Baker et al. 1998) that might lower the solidus sufficiently to enhance melt production. Elevated mantle temperatures have also been invoked as the cause of voluminous mantle melting in the region (Rooney et al. 2012b).

Melt inclusion studies from the region are sparse. Field et al. (2012a) studied melt inclusions in basaltic lavas from Erta 'Ale volcano, erupted in 2010. These contained low $\mathrm{H}_{2} \mathrm{O}$ contents $\left(<0.13 \mathrm{wt} \% \mathrm{H}_{2} \mathrm{O}\right)$, thought to reflect extensive prior degassing of the magma at shallow depth rather than initial low magmatic $\mathrm{H}_{2} \mathrm{O}$ per se. Melt inclusion data for silicic lavas from Dabbahu volcano indicated a shallow magma reservoir, with crystallisation driven by cooling rather than decompression (Field et al. 2012b). More broadly, basaltic melt inclusion studies of intraplate and riftrelated volcanic systems have focussed primarily on Hawaii [e.g., (Edmonds et al. 2013; Norman et al. 2002; Sides et al. 2014)], Iceland (Maclennan 2008; Neave et al. 2014; Winpenny and Maclennan 2011) and Piton de la Fournaise (Bureau et al. 1998) in addition to studies of Mid-Ocean Ridge Basalts [MORB; e.g., (Font et al. 2007; Nielsen et al. 1995)]. These studies reveal that there is considerable variation in mantle volatile content and provide evidence that mantle plumes may be enriched in volatiles compared to MORB (Dixon and Clague 2001; Dixon et al. 2002; Wallace 1998). Detailed studies of Icelandic magmas show a complex picture of melt evolution, mixing, and assimilation in the crust [e.g., (Shorttle et al. 2013; Winpenny and Maclennan 2011)], and this points to both the heterogeneity of the mantle source and the varied evolutionary paths that a single magma may take within the crust. The Afar region bears comparison with Iceland, in that it is a subaerial spreading centre influenced by at least one mantle plume (George et al. 1998; Hofmann et al. 1997; Pik et al. 2006; Schilling 1973).

\section{Eruptive history of Nabro}

The eruptive history of the Bidu massif is poorly known. There is evidence of large-magnitude caldera-forming eruptions at Nabro and Mallahle at the south-western end of the Bidu Massif, where rock compositions range from primitive basalt to trachyte and rhyolite (Wiart and Oppenheimer 2005). Nabro and Mallahle are two of several volcanic centres lying along the NE-SW-oriented Bidu alignment; the others include Dubbi volcano to the northeast, and Kod Ali in the Red Sea (Fig. 1). The Edd volcanic field, which lies to the north of Nabro and Dubbi, comprises lavas erupted from Dubbi volcano and associated fissures (De Fino et al. 1978). To the ENE of Dubbi, Kod Ali volcano sits offshore on a small island; its eruptive products contain abundant ultramafic nodules (Hutchison and Gass 1971). When Nabro erupted in 2011, the eruption was widely thought to be from

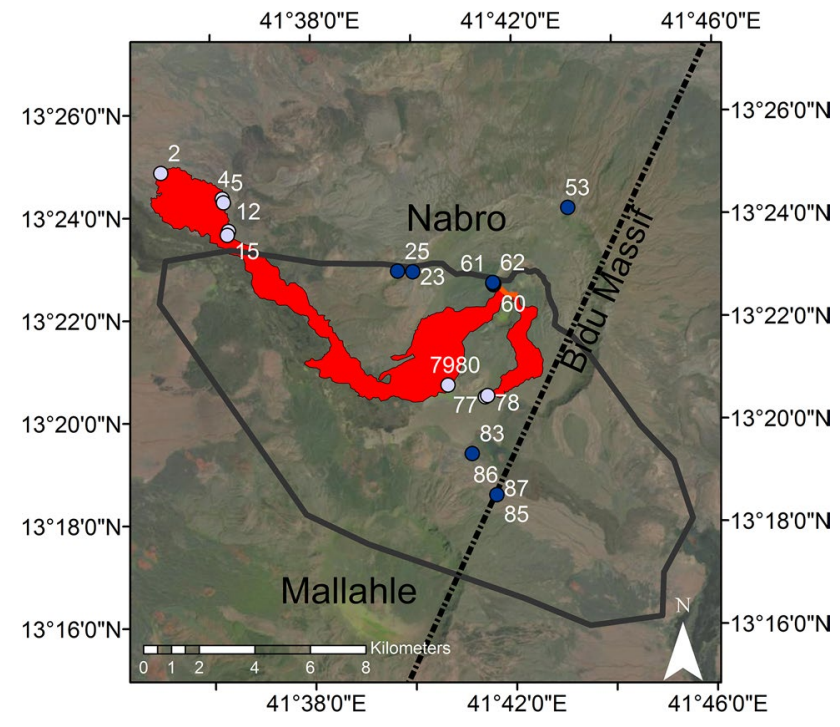

Fig. 2 Landsat image of Nabro and Mallahle volcanoes (acquired before the 2011 eruption), with a sketch of the deposits from the 2011 eruption based on ALI imagery. Lava flows are shown in red. Black outline denotes the main 2011 tephra field, which was sampled in Eritrea only. Sample locations are shown as numbered blue circles. Light blue denotes lava samples; dark blue denotes tephra samples (the focus of this paper). Dotted line indicates the axis of the Bidu Massif

Dubbi until satellite imagery became available (Theys et al. 2013).

There has been very little previous work on the petrology of Nabro volcano, the only study being the $\mathrm{PhD}$ thesis of Wiart (2005). This focussed on Dubbi, but includes wholerock analyses of ten samples from Nabro, all of which are silicic (63-74 wt $\% \mathrm{SiO}_{2}$ ), while noting the presence of more mafic units, interpreted as recent. Wiart and Oppenheimer (2005), using satellite data, described three large ignimbrite deposits, which they termed the Western, the Eastern, and the South Eastern Ignimbrites. Wiart and Oppenheimer (2005) attributed the Western Ignimbrite to Nabro and the other two to Mallahle, suggesting that all three ignimbrites may have formed in a single, very large event. In addition to the ignimbrites, they identify at least two different effusive trachytic eruptions, and a number of rhyolite flows, obsidian flows, and the recent basalts. Wiart and Oppenheimer (2005) further compared the Nabro-Mallahle volcanic system with volcanism on the other side of Afar, at Ma'alalta volcano (Fig. 1). In estimating the volume of these marginal units on the flanks of the Afar Depression, they noted that volumetrically, they are comparable with eruptive units in the rift axis itself-illustrative of voluminous off-axis volcanism.

During the 2011 eruption, activity was concentrated along a rift at $90^{\circ}$ to the Bidu Massif (Goitom et al. 2015). Two major lava flows were produced, one of which extended $\sim 15 \mathrm{~km}$ to the northwest of the volcano; the other was shorter and moved southwards within the caldera 
(Fig. 2; Goitom et al. 2015). The tephra field was welldefined to the south-west of the edifice (towards and blanketing Mallahle volcano). During the eruption, seismicity was also detected under Mallahle, raising the possibility of an underground connection between the two volcanoes [e.g., Hamlyn et al. (2014)]. The 2011 eruption represents an unprecedented opportunity to study an eruption at one of the large caldera volcanoes on the margins of the Afar Depression. Here, we analyse melt inclusions and minerals from the 2011 tephra to investigate the history of the magma that fed the eruption. Our key objectives are to constrain the volatile budget and pre-eruptive storage conditions of the 2011 magma and to identify potential eruption triggers. More broadly, these objectives allow us to contribute to understanding off-axis volcanism in Afar.

\section{Methods}

Fresh tephra samples ( $\operatorname{size}<2 \mathrm{~cm}^{3}$ ) were crushed using a jaw crusher and ball mill. Whole-rock analyses were made using X-ray fluorescence spectroscopy at Leicester University (major elements). Trace elements were measured by Inductively Coupled Plasma Mass Spectrometry (ICPMS) using a Perkin Elmer Elan DRC II instrument at the University of Cambridge, following dissolution in nitric acid and hydrofluoric acid. Phenocrysts of olivine and plagioclase were extracted from crushed samples and mounted in epoxy resin, ground and polished, and then imaged using a Hitachi S-3500N scanning electron microscope at the University of Bristol. Variable vacuum mode was used to avoid the need to carbon-coat the samples before they were ion-probed. Melt inclusions were identified and screened for devitrification textures. Most of the melt inclusions in olivine were partially devitrified; hence, most inclusions studied here are plagioclase hosted; all were glassy with no evident cracks or breaches. Most lacked shrinkage bubbles; those that did have them were noted. Melt inclusions were not rehomogenised prior to analysis for several reasons: heating experiments can affect the oxidation state of the inclusion, promoting diffusion of $\mathrm{H}$, for example (Rowe et al. 2007); it is easy to over- or under-heat melt inclusions (Nielsen 2011); and heating may cause physical changes such as cracks (Nielsen et al. 1995). The potential role of natural post-entrapment processes is discussed in "Melt inclusion compositions".

Polished grain mounts were gold-coated; 130 melt inclusions and four matrix glasses were analysed for volatiles and trace elements at the NERC Ion Microprobe Facility in Edinburgh. $\mathrm{CO}_{2}$ was measured as ${ }^{12} \mathrm{C}^{+}$on the Cameca ims-1270 instrument; $\mathrm{H}_{2} \mathrm{O}$ (as ${ }^{1} \mathrm{H}^{+}$) and "light" $(<47 \mathrm{amu})$ trace elements were measured on the Cameca ims-4f. Some inclusions were selected for additional "heavy" (>30 amu) trace element measurement on the ims-4f. For each inclusion, analyses were made in the order: $\mathrm{CO}_{2}, \mathrm{H}_{2} \mathrm{O}$ and light traces, and (where selected) heavy traces, in three separate measurements. Titanium content was used to check for consistency across all sets, and with the electron probe data.

Analyses of $\mathrm{CO}_{2}$ on the Cameca ims-1270 used a 3.8 $\mathrm{nA}$ primary beam of negatively charged oxygen dimer ions $\left(\mathrm{O}_{2}{ }^{-}\right)$at $22 \mathrm{keV}$ net impact energy focussed to a spot of approximately $15-20 \mu \mathrm{m}$. A 1-min pre-sputter with a 10 $\mu \mathrm{m}^{2}$ raster was applied. Twenty cycles were recorded and the final eight retained. Secondary ions were collected at $10 \mathrm{kV}$ with a $50 \mathrm{eV}$ offset, at sufficient mass resolution to fully resolve ${ }^{24} \mathrm{Mg}^{2+}$ from ${ }^{12} \mathrm{C}^{+}$. The $\mathrm{CO}_{2}$ concentrations were defined by a working curve using four basaltic glass standards (Lesne et al. 2011b), with a range in composition of 900-2550 ppm $\mathrm{CO}_{2}$ and a volatile-free glass blank. Backgrounds were recorded throughout the measurements using the olivine and plagioclase host crystals. Standards were measured at the start and end of each session, and data and working curves are provided as supplementary data.

Analyses for water and light trace elements on the Cameca ims-4f used a $15 \mu \mathrm{m}$ 5-6 nA primary beam of $\mathrm{O}^{-}$ions with $15 \mathrm{keV}$ net impact energy. A 1-min pre-sputter of $10 \mu \mathrm{m}^{2}$ was applied. Secondary ions were collected at $4.5 \mathrm{kV}$ with a $75 \mathrm{eV}$ offset. A field aperture was employed to restrict secondary ion collection to the central 8-10 $\mu \mathrm{m}$ of the sputtered pit to reduce background. Heavy trace elements were also measured on the Cameca ims-4f using a $15 \mu \mathrm{m}$ 5-6 nA beam with a $75 \mathrm{eV}$ offset to reduce molecular ion transmission. Positive secondary ions were measured from the full $25 \mu \mathrm{m}$ image field. Analyte isotopes were normalised to ${ }^{30} \mathrm{Si}$ and then corrected for $\mathrm{SiO}_{2}$ concentration based on EPMA measurements. Interferences from the light REE oxides and $\mathrm{BaO}$ on the heavy REE were removed by peak-stripping. Backgrounds were recorded throughout the water measurements using the olivine and plagioclase host crystals. Standards were measured at the start and end of each session. The fully propagated Gaussian errors are displayed on the data tables for $\mathrm{H}_{2} \mathrm{O}$ and $\mathrm{CO}_{2}$. For the trace elements, errors are $\pm 10 \%$. Following ion-probe analysis, major and minor element (including $\mathrm{S}, \mathrm{Cl}$, and $\mathrm{F}$ ) analysis was undertaken at the University of Cambridge using a Cameca SX100 electron microprobe. Inclusions and host glasses were measured with a $15 \mathrm{kV}$ accelerating voltage, $6 \mathrm{nA}$ beam current, and a defocused $10 \mu \mathrm{m}$ beam. Na was always analysed first to minimise alkali loss. Minerals were analysed both in the proximity of each melt inclusion and at their rims, using $15 \mathrm{kV}, 20 \mathrm{nA}$ focussed $1 \mu \mathrm{m}$ beam. Major elements were counted for 30-60 s and volatile elements for 90-120 s. Particular care was taken to measure $F$ to avoid $F$ migration in the glass. In addition to the inclusions and their hosts, measurements of phenocryst and groundmass 
Fig. 3 Total alkali-silica diagram after LeBas et al. (1986) showing the whole rock (WR), glass, and melt inclusion compositions from the 2011 eruption of Nabro. Also shown are older rocks from Nabro and samples from Edd volcanic field (De Fino et al. 1978) and a single sample from Kod Ali (an island in the Red Sea situated on the Bidu lineament; Hutchison and Gass 1971). All data are normalised to $100 \%$ anhydrous. The two batches of the 2011 magma are explained in "Petrography and mineralogy of 2011 samples". Note abscissa on axes

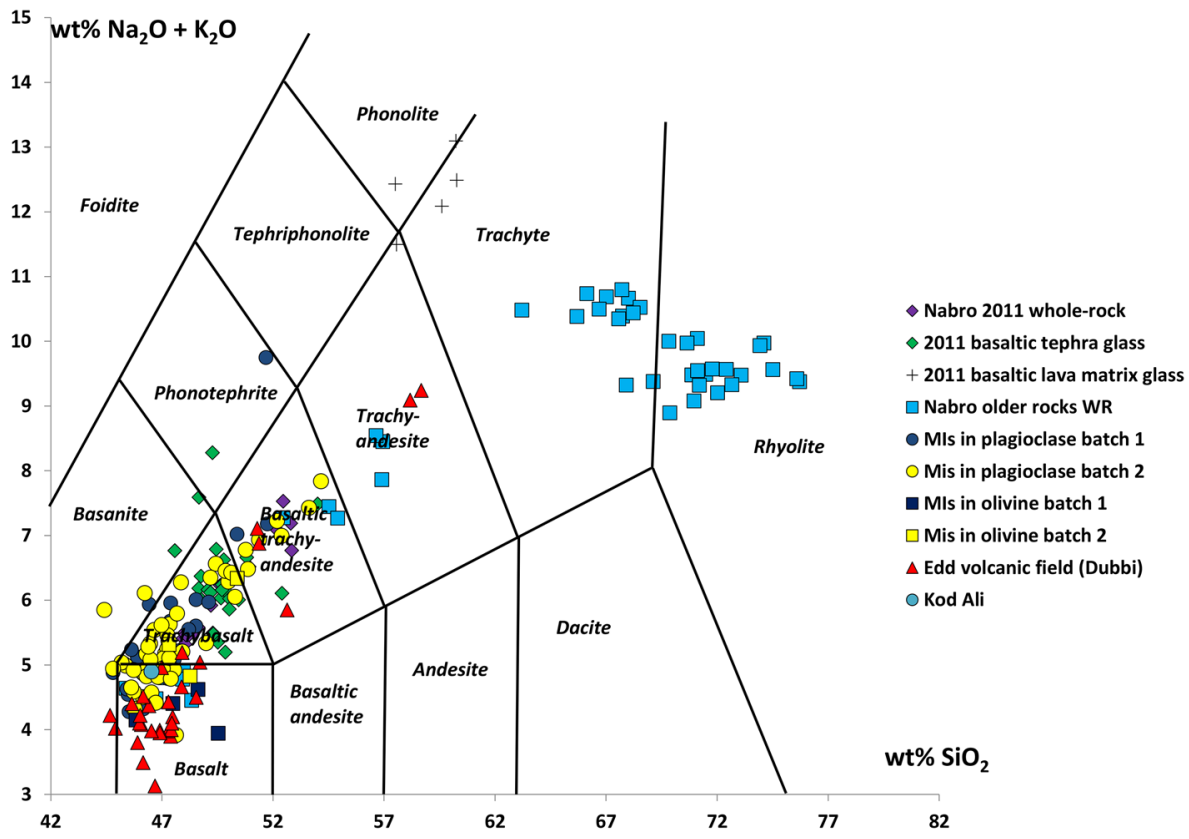

minerals were made on thin sections of both lavas and tephra from several different samples.

A number of statistical tests were performed on the data set. Where data were grouped-for example, by rock sample-the Kruskal-Wallis test was applied to look for differences between groups. Where there were only two groups, the Kolmogorov-Smirnov test was used. Both these tests are appropriate for non-parametric data sets and care was taken to ensure that small groups did not unduly influence the result. For data that had been summed to $100 \%$ and where a transformation was indicated by the distribution, the data were first transformed using a square root transformation for small values and an arcsin transformation for larger values (i.e., $\mathrm{SiO}_{2}$ ).

\section{Results}

\section{Whole-rock and glass compositions}

A total alkali-silica diagram is shown in Fig. 3. The compositions of the 2011 whole rocks (Table 1) and melt inclusions are broadly similar to older mafic rocks found on Nabro and lie on an apparent fractionation trend that extends to the rhyolitic compositions of the ancient ignimbrites. However, lava matrix glasses from the 2011 eruption are displaced to higher total alkalis, reaching eventually the phonolite field (Fig. 3). This is particularly the case for the lava flows, where plagioclase and clinopyroxene crystallisation dominate. Representative whole-rock compositions are shown in Table 1.

\section{Petrography and mineralogy of 2011 samples}

The 2011 samples contain between 15 and 30 vol\% phenocrysts. Lava samples are highly crystalline $(<3 \%$ interstitial glass) and contain abundant groundmass plagioclase $(\sim 70 \%)$, with appreciable clinopyroxene $(\sim 20 \%)$ and less than $10 \%$ olivine and $\mathrm{Fe}-\mathrm{Ti}$ oxides. Lavas are not considered further in this paper as all studied melt inclusions are from rapidly-cooled, small tephra clasts.

The 2011 tephras contain phenocrysts of olivine, clinopyroxene, plagioclase, and $\mathrm{Fe}-\mathrm{Ti}$ oxides, with minor apatite. Olivines $\left(\mathrm{Fo}_{80-85}\right)$ are typically euhedral with narrow, more fayalite-rich rims $\left(\mathrm{Fo}_{70-75}\right)$. However, some olivines are reverse zoned $\left(\mathrm{Fo}_{60}\right.$ in the core to $\mathrm{Fo}_{70}$ in the rim) or unzoned (Fig. 6). Olivine phenocrysts up to $1000 \mu \mathrm{m}$ in length contain inclusions of chromite, sometimes with magnetite mantles. Chromites also occur on the edges of olivines, always with a magnetite rim. Clinopyroxene (up to $1000 \mu \mathrm{m}$ in length) is present in two main populations-reverse zoned $\left(\sim \mathrm{Mg} \#{ }^{1} 50-60\right.$ in the core, $\sim \mathrm{Mg} \# 75-80$ at rim) and unzoned (Mg\# 75-80). Plagioclase is normally zoned, with cores up to $\sim \mathrm{An}_{80}$ and rims varying from $\mathrm{An}_{50}$ to $\mathrm{An}_{75}$. The largest crystals are $>2000 \mu \mathrm{m}$ in length. Both ilmenite and magnetite are present (typically $200 \mu \mathrm{m}$, but some larger), as are large fluorapatite crystals $(>500 \mu \mathrm{m})$.

There are two dominant primary textures in the tephra (sometimes found mingled), as well as a further fine-grained texture that is found mingled in lavas and attributed to mingling between the two tephra textures with additional cooling

\footnotetext{
${ }^{1} \mathrm{Mg} \#$ is the molar $\mathrm{Mg} /(\mathrm{Mg}+\mathrm{Fe})$ ratio using total $\mathrm{Fe}$.
} 
Table 1 Representative whole-rock compositions

\begin{tabular}{|c|c|c|c|}
\hline & $\begin{array}{l}\text { NAB-11-12 } \\
\text { Tephra }\end{array}$ & $\begin{array}{l}\text { NAB-11-2 } \\
\text { Lava }\end{array}$ & $\begin{array}{l}\text { NAB-11-4 } \\
\text { Lava }\end{array}$ \\
\hline $\mathrm{SiO}_{2}$ & 48.63 & 49.63 & 52.10 \\
\hline $\mathrm{TiO}_{2}$ & 3.11 & 2.86 & 2.40 \\
\hline $\mathrm{Al}_{2} \mathrm{O}_{3}$ & 15.61 & 15.77 & 16.24 \\
\hline $\mathrm{Fe}_{2} \mathrm{O}_{3}$ & 12.17 & 11.83 & 10.73 \\
\hline $\mathrm{MnO}$ & 0.21 & 0.22 & 0.23 \\
\hline $\mathrm{MgO}$ & 4.79 & 4.26 & 3.35 \\
\hline $\mathrm{CaO}$ & 8.63 & 7.79 & 6.85 \\
\hline $\mathrm{Na}_{2} \mathrm{O}$ & 4.17 & 4.57 & 5.21 \\
\hline $\mathrm{K}_{2} \mathrm{O}$ & 1.41 & 1.66 & 1.90 \\
\hline $\mathrm{P}_{2} \mathrm{O}_{5}$ & 1.02 & 0.98 & 0.90 \\
\hline $\mathrm{SO}_{3}$ & 0.06 & 0.03 & 0.02 \\
\hline Mg\# & 41.24 & 39.10 & 35.76 \\
\hline LOI & -0.49 & -0.55 & -0.51 \\
\hline Total & 99.33 & 99.07 & 99.42 \\
\hline $\mathrm{Li}$ & 9.64 & 9.54 & 11.53 \\
\hline $\mathrm{Be}$ & 1.96 & 2.07 & 2.30 \\
\hline $\mathrm{Sc}$ & 41.14 & 26.76 & 22.93 \\
\hline V & 255.51 & 191.52 & 127.56 \\
\hline $\mathrm{Cr}$ & 51.72 & 32.48 & 10.35 \\
\hline Co & 28.83 & 22.75 & 14.67 \\
\hline $\mathrm{Ni}$ & 28.29 & 21.60 & 6.76 \\
\hline $\mathrm{Cu}$ & 33.60 & 27.34 & 15.62 \\
\hline $\mathrm{Zn}$ & 123.73 & 128.19 & 130.52 \\
\hline $\mathrm{Ga}$ & 24.01 & 24.67 & 25.41 \\
\hline $\mathrm{Rb}$ & 37.25 & 42.49 & 50.12 \\
\hline $\mathrm{Sr}$ & 783.87 & 759.62 & 772.04 \\
\hline Y & 44.68 & 48.79 & 52.29 \\
\hline $\mathrm{Zr}$ & 303.21 & 352.95 & 405.57 \\
\hline $\mathrm{Nb}$ & 77.05 & 86.86 & 97.49 \\
\hline Sn & 2.23 & 2.77 & 2.60 \\
\hline Cs & 0.30 & 0.33 & 0.41 \\
\hline $\mathrm{Ba}$ & 451.85 & 518.98 & 608.96 \\
\hline $\mathrm{La}$ & 56.38 & 64.99 & 71.89 \\
\hline $\mathrm{Ce}$ & 120.13 & 134.48 & 148.07 \\
\hline $\operatorname{Pr}$ & 14.75 & 16.51 & 18.22 \\
\hline $\mathrm{Nd}$ & 62.73 & 67.67 & 73.17 \\
\hline $\mathrm{Sm}$ & 12.22 & 13.24 & 13.81 \\
\hline $\mathrm{Eu}$ & 4.09 & 4.43 & 4.79 \\
\hline Gd & 10.52 & 11.31 & 11.80 \\
\hline $\mathrm{Tb}$ & 1.58 & 1.67 & 1.80 \\
\hline Dy & 8.57 & 9.20 & 9.86 \\
\hline Но & 1.58 & 1.72 & 1.90 \\
\hline Er & 4.08 & 4.45 & 4.81 \\
\hline $\mathrm{Tm}$ & 0.57 & 0.61 & 0.67 \\
\hline $\mathrm{Yb}$ & 3.28 & 3.61 & 4.02 \\
\hline $\mathrm{Lu}$ & 0.47 & 0.51 & 0.58 \\
\hline $\mathrm{Hf}$ & 7.37 & 8.28 & 9.38 \\
\hline $\mathrm{Ta}$ & 4.82 & 5.39 & 5.94 \\
\hline $\mathrm{Tl}$ & 0.04 & 0.04 & 0.02 \\
\hline $\mathrm{Pb}$ & 3.25 & 3.29 & 3.85 \\
\hline Th & 5.65 & 6.61 & 7.62 \\
\hline $\mathrm{U}$ & 1.53 & 1.79 & 2.09 \\
\hline
\end{tabular}

Table 1 (continued)

Major elements measured by XRF, trace elements by ICPMS. All data plotted in this paper are available in Supplementary Data

(see, for example, Fig. 4f). We identify two distinct batches of magma based on the primary textural features of tephra groundmass (Table 2). Batch 1 is very glassy and almost all of the phenocrysts and microlites are plagioclase, with lesser clinopyroxene; phenocrysts are often unzoned (Fig. 4a, b). Batch 2 is highly crystalline ( $>70 \%$ total crystals) and dominated by plagioclase, followed by clinopyroxene, olivine, and oxides (Fig. 4c, d). Phenocrysts of these minerals and minor apatite occur, many showing zonation. While there are some compositional differences between the two batches of magma, bulk-rock and mineral chemistries are very similar. The whole-rock composition of the plagioclase-rich magma (Batch 1) is slightly richer in $\mathrm{Al}_{2} \mathrm{O}_{3}$ and $\mathrm{MgO}$, and poorer in $\mathrm{P}_{2} \mathrm{O}_{5}$, compared with Batch 2 .

Also present in the rocks are larger crystals $(>1 \mathrm{~mm})$, sometimes aggregated, which show disequilibrium textures and which we consider to be xenocrysts. These include plagioclase, olivine, clinopyroxene, orthopyroxene, and magnetite. One magnetite crystal $(>2 \mathrm{~mm})$ is unzoned. Olivines (up to $2 \mathrm{~mm}$ in size) are more $\mathrm{Mg}$-rich than $\mathrm{Fo}_{85}$, and clinopyroxene has $\mathrm{Mg \#} \sim 80$. Both show minor zoning towards Fe-rich compositions at their rims. One highly reacted anorthoclase crystal was also observed. Plagioclase megacrysts $(>2 \mathrm{~mm})$ with high-An cores $(>85)$ occur rarely.

The glassy melt inclusions studied here were mostly found in plagioclase phenocrysts, with a lesser number hosted by olivine (Fig. 5; Table 3). A few small melt inclusions in clinopyroxene were measured with the electron probe only. The host crystals generally follow the patterns above. In the plagioclase hosts, there are two sub groups, one with $\mathrm{An}_{80-71}$ and one with $\mathrm{An}_{66-58}$. Figure 6 shows the core and rim compositions of olivine and plagioclase crystals, whose melt inclusions we investigate here. For plagioclase hosts, in particular, there are two primary groups-normally zoned and unzoned (Fig. 6). There is no difference in host mineral compositions between the two texturally-identified magma batches.

\section{Melt inclusion compositions}

Figure 7 shows the melt inclusions, glass, and whole-rock compositions from the 2011 eruption, and whole-rock and glass compositions from the ancient ignimbrites for reference. As shown in Fig. 7, the 2011 magma is fractionated $(\mathrm{Mg} \# \sim 40)$ and rich in $\mathrm{TiO}_{2}(\sim 3 \mathrm{wt} \%)$ and total $\mathrm{FeO}$ $(\sim 12 \mathrm{wt} \%)$. More evolved samples are hypersthene normative, while those with $<50 \mathrm{wt} \% \mathrm{SiO}_{2}$ are slightly nepheline normative. Melt inclusions are mostly nepheline normative regardless of $\mathrm{SiO}_{2}$ content. Melt inclusions are generally 

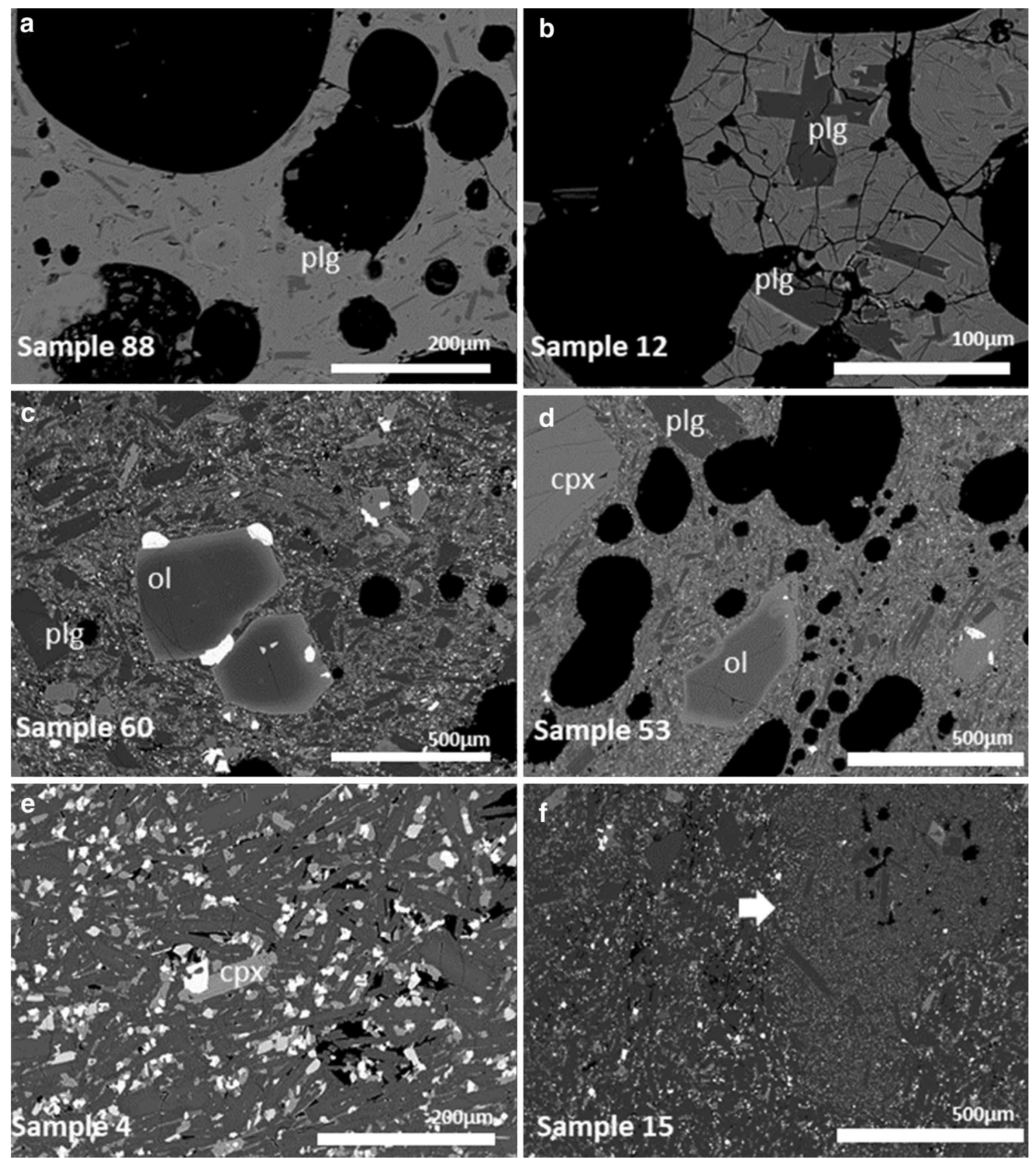

Fig. 4 Back-scattered electron micrographs of the 2011 eruptive products. a, b Show tephra "Batch 1", c, d show tephra "Batch 2", and e, f are from lava samples. Note the presence of a vesicular, finer grained component in $\mathbf{f}$ (arrow) - this phenomenon is also found in the tephra

Table 2 Average modal proportions of minerals and glass in the groundmass of the two main tephra textures (Batch 1 and Batch 2) and the proportion of phenocrysts relative to groundmass

\begin{tabular}{lllclcc}
\hline Batch & $\%$ Plag & $\% \mathrm{Ol}$ & $\% \mathrm{cpx}$ & $\% \mathrm{Fe}-\mathrm{Ti}$ & $\%$ Glass & $\%$ Phenocrysts \\
\hline 1 & 24 & 2 & 2 & 0 & 72 & 29 \\
2 & 50 & 7 & 15 & 8 & 20 & 15 \\
\hline
\end{tabular}

Standard deviation is $10 \%$ for both types - there is considerable variation. All data obtained by point counting of thin sections (1000 points per section) and analysis of back-scattered electron micrographs in ImageJ 
Fig. 5 Examples of melt inclusions in olivine and plagioclase phenocrysts

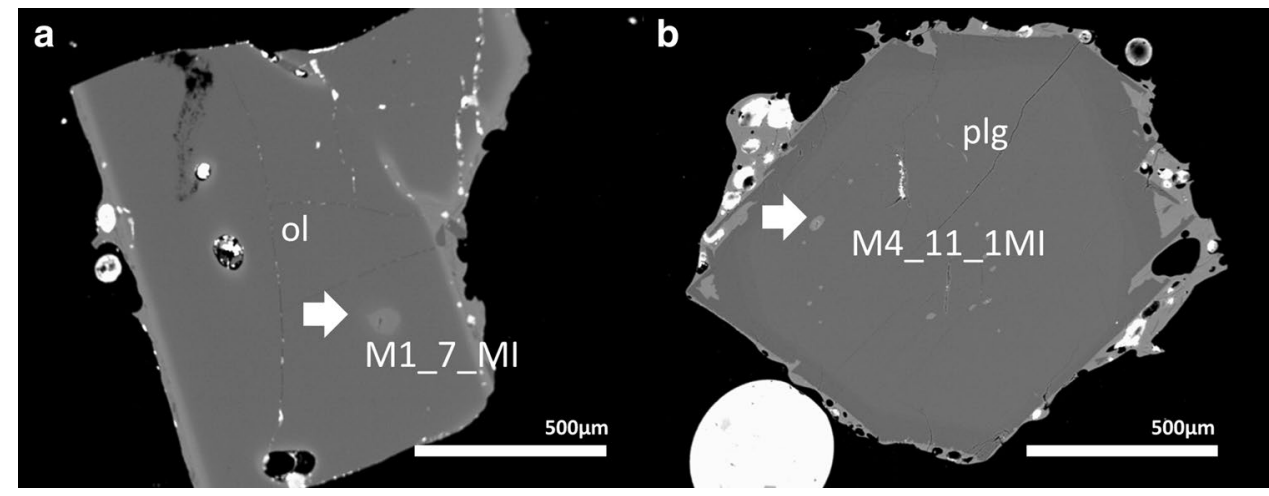

basaltic, trending to trachybasalt (Fig. 3) and follow the same evolutionary trend apparent in whole-rock compositions for older products of Nabro. However, an alkali-enriched trend is also present in some of the inclusions and in the matrix glass (Tables 4, 5), consistent with a greater role for clinopyroxene crystallisation in groundmass composition relative to phenocryst proportions. This suggests that the chemical processes responsible for generation of the groundmass glass chemistry (i.e., crystallisation at low pressure during eruption and ascent) differ from those responsible for the wholerock trends.

Major element compositions of the whole rocks reflect the phase assemblage-olivine, plagioclase, clinopyroxene, magnetite, ilmenite, and minor apatite. There is a clear peak in the $\mathrm{SiO}_{2}-\mathrm{P}_{2} \mathrm{O}_{5}$ plot at the point of apatite saturation. There is no $\mathrm{TiO}_{2}$ fractionation peak, suggesting that ilmenite was forming throughout crystallisation, though the slightly higher $\mathrm{TiO}_{2}$ in the glasses might indicate that magnetite (containing 17-24 wt\% $\mathrm{TiO}_{2}$ ) dominated in the shallow system; this would be consistent with the magnetite mantles on chromite and its dominance in the groundmass. The differentiation trend in the whole rocks is less extensive than in the glasses. Some of the melt inclusions are more evolved than the groundmass, which may imply that these inclusions are contained in crystals that were stored in a crystal-rich magma reservoir before being remobilised prior to eruption. We show below that post-entrapment crystallisation of the host mineral cannot account for this behaviour.

Trace element contents are suggestive of a simple fractionation trend, though there is some scatter. Incompatible trace elements generally increase with decreasing $\mathrm{MgO}$, while compatible elements decrease. Rare-earth elements (REEs) are generally enriched, and $\mathrm{La} / \mathrm{Yb}$ in the whole rock is 17.7-18.1 (PM-normalised 12.3-13.2).

The melt inclusions display considerable variation in their major element chemistry (Fig. 7)—generally much wider than that seen in the whole-rock data, though they follow it closely. The range of $\mathrm{Mg \#} \mathrm{(54-35)} \mathrm{is} \mathrm{also} \mathrm{greater,}$ but $\mathrm{MgO}$ does not show a simple, negative linear correlation with incompatible elements such as $\mathrm{La}$ and $\mathrm{Zr}$. Melt inclusions in olivine have consistently lower contents of $\mathrm{FeO}, \mathrm{K}_{2} \mathrm{O}$, and $\mathrm{P}_{2} \mathrm{O}_{5}$, and higher abundances of $\mathrm{CaO}$ and $\mathrm{Al}_{2} \mathrm{O}_{3}$ than those in plagioclase. They also have slightly lower abundances of incompatible trace elements. The inclusions in plagioclase track the liquid line of descent of the whole rocks closely.

Melt inclusions in plagioclase can be divided into two groups based on chemical zonation of the host phenocrysts (Fig. 6). The most evolved melt inclusions are found exclusively in unzoned phenocrysts or those with very slight reverse zoning. The most primitive inclusions are found in the high-An (75-80) cores of zoned phenocrysts, but there are some primitive inclusions in high-An unzoned phenocrysts. While both zoned and unzoned crystals are found in samples from both batches, the unzoned crystals are more common in Batch 1 (glassy). Melt inclusions in zoned plagioclase crystals are generally less evolved than those in unzoned crystals. All melt inclusions are strongly enriched in the LREEs relative to HREEs (Fig. 8).

\section{Boundary-layer effects}

A common cause of variation in melt inclusion composition is the influence of a boundary layer of melt around the crystal present during rapid growth (Baker 2008; Kent 2008; Métrich and Wallace 2008). This can affect slowdiffusing components, such as $\mathrm{Al}_{2} \mathrm{O}_{3}$ or $\mathrm{P}_{2} \mathrm{O}_{5}$, but would not impact $\mathrm{Na}_{2} \mathrm{O}$ or $\mathrm{CaO}$ due to their higher diffusivity. Furthermore, this effect is typically only found in small inclusions [ $<15 \mu \mathrm{m}$; (Kuzmin and Sobolev 2003)], and is dominantly observed in experiments (e.g., Baker 2008). Since the beam size for the ion microprobe is $>30 \mu \mathrm{m}$, we did not study any inclusions smaller than this. Kent (2008) estimates that inclusions $>30 \mu \mathrm{m}$ in diameter should be free from boundary-layer effects under natural magmatic conditions. The observed trends at Nabro for both melt inclusions and whole rocks show a clear fractionation peak for $\mathrm{P}_{2} \mathrm{O}_{5}$ (Fig. 7) that is hard to reconcile with boundarylayer effects. 
Table 3 Representative melt inclusion host phenocryst compositions

\begin{tabular}{|c|c|c|c|c|c|c|c|c|}
\hline \multicolumn{2}{|l|}{ a. Olivine } & \multicolumn{2}{|c|}{ NAB11-S4-2-1 } & \multicolumn{3}{|c|}{ NAB11-M4-4-1 } & \multicolumn{2}{|c|}{ NAB11-M3-16-2 } \\
\hline \multicolumn{9}{|l|}{ Ol cores } \\
\hline \multicolumn{2}{|l|}{$\mathrm{SiO}_{2}$} & \multicolumn{2}{|l|}{38.49} & \multicolumn{3}{|c|}{39.66} & \multicolumn{2}{|c|}{39.32} \\
\hline \multicolumn{2}{|l|}{$\mathrm{TiO}_{2}$} & \multicolumn{2}{|l|}{0.02} & \multicolumn{3}{|c|}{0.02} & \multicolumn{2}{|c|}{0.03} \\
\hline \multicolumn{2}{|l|}{$\mathrm{Al}_{2} \mathrm{O}_{3}$} & \multicolumn{2}{|l|}{0.04} & \multicolumn{3}{|c|}{0.06} & \multicolumn{2}{|c|}{0.05} \\
\hline \multicolumn{2}{|l|}{ FeOT } & \multicolumn{2}{|l|}{16.92} & \multicolumn{3}{|c|}{17.19} & & \\
\hline $\mathrm{MnO}$ & & 0.20 & & & 0.28 & & & \\
\hline $\mathrm{MgO}$ & & 43.10 & & & 43.33 & & & \\
\hline $\mathrm{CaO}$ & & 0.25 & & & 0.27 & & & \\
\hline $\mathrm{Na}_{2} \mathrm{O}$ & & 0.01 & & & 0.02 & & & \\
\hline $\mathrm{K}_{2} \mathrm{O}$ & & 0.01 & & & 0.01 & & & \\
\hline $\mathrm{P}_{2} \mathrm{O}_{5}$ & & 0.01 & & & 0.01 & & & \\
\hline $\mathrm{Cr}_{2} \mathrm{O}_{3}$ & & 0.04 & & & 0.01 & & & \\
\hline $\mathrm{NiO}$ & & 0.23 & & & 0.25 & & & \\
\hline Total & & 99.32 & & & 101.11 & & & \\
\hline Fo & & 81.95 & & & 81.79 & & & \\
\hline $\mathrm{Fa}$ & & 18.05 & & & 18.21 & & & \\
\hline Ol rims & & & & & & & & \\
\hline $\mathrm{SiO}_{2}$ & & 37.54 & & & 38.47 & & & \\
\hline $\mathrm{TiO}_{2}$ & & 0.02 & & & 0.05 & & & \\
\hline $\mathrm{Al}_{2} \mathrm{O}_{3}$ & & 0.04 & & & 0.03 & & & \\
\hline FeOT & & 16.81 & & & 24.63 & & & \\
\hline $\mathrm{MnO}$ & & 0.22 & & & 0.38 & & & \\
\hline $\mathrm{MgO}$ & & 41.15 & & & 37.90 & & & \\
\hline $\mathrm{CaO}$ & & 0.26 & & & 0.26 & & & \\
\hline $\mathrm{Na}_{2} \mathrm{O}$ & & 0.03 & & & 0.03 & & & \\
\hline $\mathrm{K}_{2} \mathrm{O}$ & & 0.00 & & & 0.00 & & & \\
\hline $\mathrm{P}_{2} \mathrm{O}_{5}$ & & 0.01 & & & 0.06 & & & \\
\hline $\mathrm{Cr}_{2} \mathrm{O}_{3}$ & & 0.02 & & & 0.02 & & & \\
\hline $\mathrm{NiO}$ & & 0.20 & & & 0.11 & & & \\
\hline Total & & 96.30 & & & 101.95 & & & \\
\hline Fo & & 81.35 & & & 73.28 & & & \\
\hline $\mathrm{Fa}$ & & 18.65 & & & 26.72 & & & \\
\hline b. Plagioclase & $\begin{array}{l}\text { NAB11- } \\
\text { M4-11-1 }\end{array}$ & $\begin{array}{l}\text { NAB11- } \\
\text { S4-16-2 }\end{array}$ & $\begin{array}{l}\text { NAB11- } \\
\text { M4-6-2 }\end{array}$ & $\begin{array}{l}\text { NAB11- } \\
\text { S4-11-1 }\end{array}$ & $\begin{array}{l}\text { NAB11- } \\
\text { M4-22-1 }\end{array}$ & $\begin{array}{l}\text { NAB11- } \\
\text { M4-18-2 }\end{array}$ & $\begin{array}{l}\text { NAB11- } \\
\text { M1-3-1 }\end{array}$ & $\begin{array}{l}\text { NAB11- } \\
\text { S4-19-1 }\end{array}$ \\
\hline Plag cores & & & & & & & & \\
\hline $\mathrm{SiO}_{2}$ & 46.95 & 48.47 & 50.22 & 46.95 & 52.99 & 48.58 & 52.42 & 51.09 \\
\hline $\mathrm{TiO}_{2}$ & 0.03 & 0.06 & 0.07 & 0.10 & 0.05 & 0.06 & 0.11 & 0.10 \\
\hline $\mathrm{Al}_{2} \mathrm{O}_{3}$ & 32.75 & 31.32 & 31.81 & 31.85 & 28.29 & 31.09 & 29.55 & 29.40 \\
\hline FeOT & 0.52 & 0.59 & 0.71 & 0.58 & 0.49 & 0.58 & 0.45 & 0.48 \\
\hline $\mathrm{MnO}$ & & & & & & & 0.03 & \\
\hline $\mathrm{MgO}$ & 0.08 & 0.08 & 0.08 & 0.08 & 0.07 & 0.08 & 0.08 & 0.06 \\
\hline $\mathrm{CaO}$ & 16.21 & 14.87 & 14.82 & 15.92 & 11.18 & 14.84 & 12.14 & 12.74 \\
\hline $\mathrm{Na}_{2} \mathrm{O}$ & 1.91 & 2.78 & 3.08 & 2.36 & 4.88 & 2.84 & 4.36 & 3.94 \\
\hline $\mathrm{K}_{2} \mathrm{O}$ & 0.10 & 0.12 & 0.15 & 0.11 & 0.20 & 0.13 & 0.19 & 0.18 \\
\hline $\mathrm{SrO}$ & 0.16 & 0.22 & 0.17 & 0.16 & 0.21 & 0.11 & 0.15 & 0.15 \\
\hline Total & 98.75 & 98.56 & 101.11 & 98.11 & 98.39 & 98.36 & 99.52 & 98.17 \\
\hline An & 81.93 & 74.19 & 72.03 & 78.34 & 55.21 & 73.69 & 59.93 & 63.43 \\
\hline Plag rims & & & & & & & & \\
\hline $\mathrm{SiO}_{2}$ & 50.34 & 48.69 & 50.04 & 47.82 & 51.38 & 51.32 & 52.13 & 51.93 \\
\hline
\end{tabular}


Table 3 (continued)

\begin{tabular}{|c|c|c|c|c|c|c|c|c|}
\hline b. Plagioclase & $\begin{array}{l}\text { NAB11- } \\
\text { M4-11-1 }\end{array}$ & $\begin{array}{l}\text { NAB11- } \\
\text { S4-16-2 }\end{array}$ & $\begin{array}{l}\text { NAB11- } \\
\text { M4-6-2 }\end{array}$ & $\begin{array}{l}\text { NAB11- } \\
\text { S4-11-1 }\end{array}$ & $\begin{array}{l}\text { NAB11- } \\
\text { M4-22-1 }\end{array}$ & $\begin{array}{l}\text { NAB11- } \\
\text { M4-18-2 }\end{array}$ & $\begin{array}{l}\text { NAB11- } \\
\text { M1-3-1 }\end{array}$ & $\begin{array}{l}\text { NAB11- } \\
\text { S4-19-1 }\end{array}$ \\
\hline $\mathrm{TiO}_{2}$ & 0.17 & 0.08 & 0.07 & 0.06 & 0.12 & 0.09 & 0.12 & 0.11 \\
\hline $\mathrm{Al}_{2} \mathrm{O}_{3}$ & 29.65 & 30.68 & 31.44 & 32.70 & 29.38 & 29.69 & 29.25 & 29.17 \\
\hline FeOT & 0.64 & 0.60 & 0.61 & 0.56 & 0.50 & 0.60 & 0.66 & 0.68 \\
\hline $\mathrm{MnO}$ & & & & & & & 0.05 & \\
\hline $\mathrm{MgO}$ & 0.09 & 0.09 & 0.07 & 0.08 & 0.11 & 0.09 & 0.08 & 0.11 \\
\hline $\mathrm{CaO}$ & 12.86 & 14.27 & 14.38 & 16.03 & 12.65 & 12.65 & 12.49 & 12.34 \\
\hline $\mathrm{Na}_{2} \mathrm{O}$ & 3.77 & 3.01 & 3.15 & 2.22 & 4.06 & 4.05 & 4.15 & 4.20 \\
\hline $\mathrm{K}_{2} \mathrm{O}$ & 0.17 & 0.09 & 0.16 & 0.11 & 0.20 & 0.21 & 0.22 & 0.21 \\
\hline $\mathrm{SrO}$ & 0.14 & 0.19 & 0.15 & 0.12 & 0.21 & 0.15 & 0.16 & 0.15 \\
\hline Total & 97.84 & 97.69 & 100.08 & 99.70 & 98.60 & 98.87 & 99.35 & 98.91 \\
\hline An & 64.64 & 71.98 & 70.93 & 79.43 & 62.53 & 62.55 & 61.61 & 61.11 \\
\hline
\end{tabular}

'Core' compositions are sampled close to melt inclusion

Fig. 6 Rim and core compositions of the phenocrysts of plagioclase and olivine that hosted the melt inclusions. Batch 1 is blue and Batch 2 is yellow
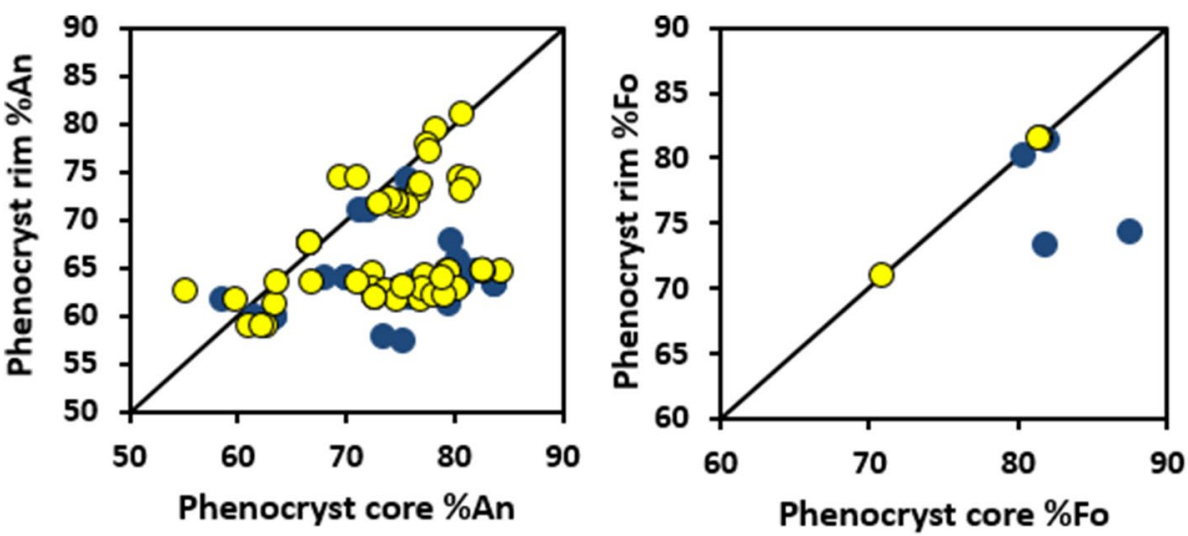

\section{Post-entrapment processes}

Olivine Post-entrapment crystallisation (PEC) for the olivine-hosted inclusions is $<4 \mathrm{wt} \%$, based on an analysis using Petrolog3 (Danyushevsky and Plechov 2011). Only three inclusions have lost $\mathrm{FeOT}$ relative to $\mathrm{MgO}$. The calculated extent of PEC cannot explain the chemical differences between the plagioclase-hosted inclusions and those in olivine. In light of the limited evidence for PEC, we have not incorporated post-entrapment corrections to the data set, because such corrections would increase uncertainty rather than mitigate it-we present corrected compositions in supplementary data for reference.

Plagioclase Post-entrapment diffusion of trace elements through plagioclase has been investigated by several authors (Cherniak 2003; Cottrell et al. 2002). Of particular interest are $\mathrm{Sr}, \mathrm{Ba}$, and $\mathrm{Eu}$, which are compatible in plagioclase. We investigated this in comparison with the olivine-hosted melt inclusions and the whole-rock data. While the olivine-hosted inclusions are slightly lower in
$\mathrm{Sr}$, there are no significant differences between the two groups in $\mathrm{Sr}$ or $\mathrm{Ba}$ relative to either $\mathrm{SiO}_{2}$ or $\mathrm{MgO}$, and no difference in the magnitude of the $\mathrm{Eu}$ anomaly $\left(\mathrm{Eu} / \mathrm{Eu}^{*}\right.$ $\sim 0.3$ ). Again, we conclude that the difference in major element composition of the olivine-hosted inclusions and those in plagioclase cannot be explained by any postentrapment or boundary-layer effects. The only major differences between the olivine-hosted inclusions and those in plagioclase are in $\mathrm{Al}_{2} \mathrm{O}_{3}, \mathrm{FeOT}, \mathrm{CaO}$, and $\mathrm{K}_{2} \mathrm{O}$. This combination cannot be explained by post-entrapment processes, but could be explained by crystallisation order ("MELTS modelling").

\section{Presence of bubbles}

We checked the melt inclusions with bubbles (present in $<20 \%$ of inclusions) but found no deviations from the trends observed in the full data set. We, therefore, do not believe that significant $\mathrm{CO}_{2}$ was present in the shrinkage bubbles. 

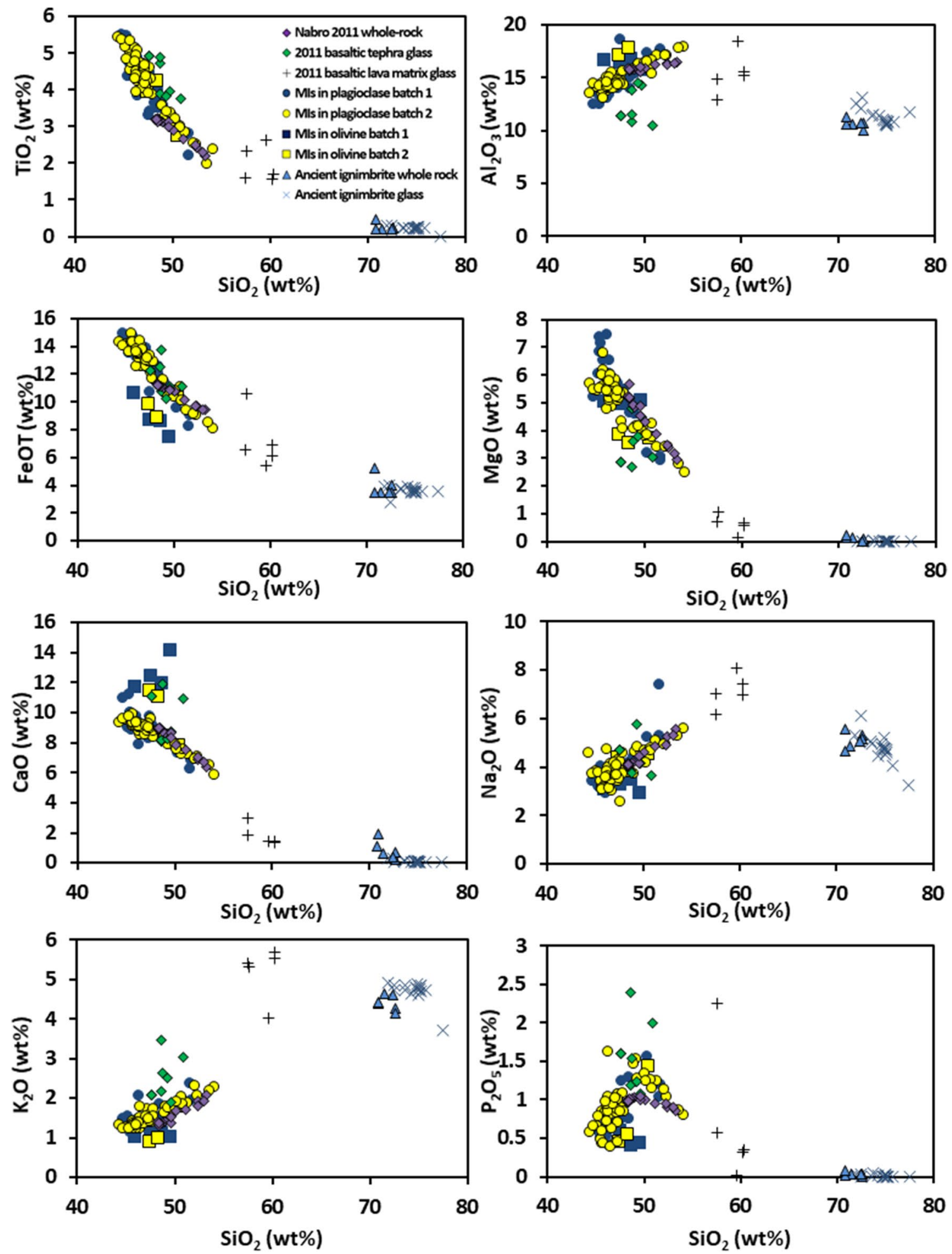

Fig. 7 Major element Harker diagrams for whole rocks (purple diamonds), tephra glasses (green diamonds), lava glasses (black crosses), and melt inclusions in plagioclase (circles) and olivine (squares). Blue denotes samples from Batch 1; yellow is Batch 2. Also shown are ancient ignimbrite whole rock (light blue triangles) and ancient ignimbrite glass (light blue crosses). Whole-rock $\mathrm{Fe}_{2} \mathrm{O}_{3}$ recalculated as FeOT. All data normalised to $100 \%$ anhydrous 
Table 4 Representative glass analyses, measured using electron probe microanalysis

\begin{tabular}{lcccc}
\hline & $\begin{array}{l}\text { NAB-11-4 } \\
\text { Lava }\end{array}$ & $\begin{array}{l}\text { NAB-11-78 } \\
\text { Lava }\end{array}$ & $\begin{array}{l}\text { NAB-11-53 } \\
\text { Tephra }\end{array}$ & $\begin{array}{l}\text { NAB-11-12 } \\
\text { Tephra }\end{array}$ \\
\hline $\mathrm{SiO}_{2}$ & 58.6371 & 61.0837 & 48.7402 & 49.6084 \\
$\mathrm{TiO}_{2}$ & 2.5785 & 1.7254 & 4.7249 & 3.9415 \\
$\mathrm{Al}_{2} \mathrm{O}_{3}$ & 18.1245 & 15.345 & 10.7693 & 14.2698 \\
$\mathrm{FeOT}$ & 5.3103 & 7.0254 & 13.8071 & 11.0998 \\
$\mathrm{MnO}$ & 0.1067 & 0.1111 & 0.5189 & 0.2441 \\
$\mathrm{MgO}$ & 0.135 & 0.6591 & 2.6741 & 4.4892 \\
$\mathrm{CaO}$ & 1.4267 & 1.3847 & 8.123 & 8.7172 \\
$\mathrm{Na} 2 \mathrm{O}$ & 7.9416 & 7.0637 & 4.1329 & 4.1254 \\
$\mathrm{~K} 2 \mathrm{O}$ & 3.9483 & 5.5937 & 3.4701 & 1.9028 \\
$\mathrm{P}_{2} \mathrm{O}_{5}$ & 0.0133 & 0.361 & 2.4016 & 1.0809 \\
$\mathrm{SO}_{2}$ & 0.0097 & 0.1136 & 0.0278 & 0.0285 \\
$\mathrm{Cl}$ & 0.0175 & 0.3994 & 0.2541 & 0.084 \\
$\mathrm{~F}$ & 0 & 0.3257 & 0.5095 & 0.28 \\
$\mathrm{Total}$ & 98.3752 & 101.3474 & 100.1536 & 99.8941 \\
\hline
\end{tabular}

\section{Melt inclusion volatile contents}

Melt inclusions contain up to $3455 \mathrm{ppm} \mathrm{CO}_{2}$, and $2.1 \mathrm{wt} \%$ $\mathrm{H}_{2} \mathrm{O}$ (Fig. 9). $\mathrm{S} / \mathrm{Cl}$ in inclusions is relatively low $(0.5-5$ by mass); $\mathrm{F} / \mathrm{Cl}$ is $0.5-5$ by mass, with $\mathrm{F}$ up to $0.32 \mathrm{wt} \%$. A few melt inclusions in xenocrysts have been measured by electron microprobe, but are rare. Two of these melt inclusions, one in plagioclase and one in olivine, contained $>7000 \mathrm{ppm}$ F.

Sulphur contents range from 200 to $3000 \mathrm{ppm}$. They are more variable than $\mathrm{Cl}$ and $\mathrm{F}$ with which they show no correlation suggesting that these different volatile species degas at different pressures, consistent with experimental work (Lesne et al. 2011a). The peak in the $\mathrm{S}-\mathrm{H}_{2} \mathrm{O}$ plot (Fig. 9a) at around $1 \mathrm{wt} \% \mathrm{H}_{2} \mathrm{O}$ suggests that the partitioning of $\mathrm{S}$ into another phase (fluid or crystal) is enhanced at low pressures when the $\mathrm{H}_{2} \mathrm{O}$ content of the melt is low. The appearance of a small sulphide crystal in melt inclusions with the highest S contents (Fig. 9a) and the widespread presence of sulphide globules in the melt suggests that sulphide saturation plays a role in controlling the behaviour of sulphur. In contrast, the substantial decrease in $\mathrm{S}$, at near-constant $\mathrm{Cl}$ (Fig. 9f), suggests that $\mathrm{Cl}$ becomes enriched by crystallisation, while $\mathrm{S}$ is actively partitioning into the fluid or sulphide phase, such that $\mathrm{Cl}$ degassing is a relatively late-stage process. The tendency of $\mathrm{Cl}$ to behave as an incompatible element is supported by its correlation with $\mathrm{K}_{2} \mathrm{O}$ (Fig. 9e). $\mathrm{CO}_{2}$ and $\mathrm{S}$ are weakly correlated (Fig. 9c). Although these components may partition similarly into the fluid phase, $\mathrm{CO}_{2}$ will not be sequestered by sulphide minerals and this may confer scatter. The $\mathrm{CO}_{2}-\mathrm{H}_{2} \mathrm{O}$ plot (Fig. 9d), like $\mathrm{S}-\mathrm{H}_{2} \mathrm{O}$, shows a maximum at intermediate $\mathrm{H}_{2} \mathrm{O}$ contents. It is clear that this cannot simply be a decompression degassing trend, as this would see a sharp drop in $\mathrm{CO}_{2}$ at near-constant $\mathrm{H}_{2} \mathrm{O}$ (Newman and Lowenstern 2002). Instead, the $\mathrm{CO}_{2}-\mathrm{H}_{2} \mathrm{O}$ behaviour is suggestive of other processes driving degassing as discussed below.

\section{Discussion}

Here, we use the volatile and trace element data presented above to investigate the magmatic system feeding the 2011 eruption. Initially, we examine trends in volatile and trace element composition, and use this information to model intrinsic variables and draw inferences. We then examine the melt inclusion evidence for multiple batches of magma as identified from textures. Finally, we model the chemical data using rhyolite-MELTS (Gualda and Ghiorso 2015, 2012).

\section{Volatile-trace element systematics}

Incompatible trace elements generally increase as volatile abundances decrease, except for the most primitive melt inclusions, which show a slight increase in $\mathrm{CO}_{2}$ with increasing incompatible trace elements. If we assume that the degree of melt crystallisation is equal to $1-F$ (where $F$ is melt fraction, $F=C_{\mathrm{l}} / C_{\mathrm{m}}$ ), and use a highly incompatible element (Ba) to calculate $F$, we obtain the relationship shown in Fig. 10, which shows that some of the melt inclusions increase in $\mathrm{CO}_{2}$ as crystallisation increases: there is a positive correlation between $\mathrm{CO}_{2}$ and incompatible trace elements (Ba, $\mathrm{Th}$, and $\mathrm{Zr}$ ). We suggest that these melt inclusions are vapour-undersaturated (Fig. 10), and, therefore, not suitable for the calculation of saturation pressures. However, we note that the high values of incompatible elements (particularly $\mathrm{Nb}$ and $\mathrm{Ba}$ ), and correspondingly low values of $\mathrm{CO}_{2} / \mathrm{Nb}$ and $\mathrm{CO}_{2} / \mathrm{Ba}$, are at odds with studies on other volatile-undersaturated basaltic samples (Hudgins et al. 2015; Le Voyer et al. 2017; Longpré et al. 2017; Rosenthal et al. 2015). We make two comments about this. First, very little is known about the mantle source composition beneath Afar, particularly for the marginal ranges, in terms of volatiles and incompatible trace elements. Thus, caution should be exercised when making comparisons to other volcanic settings. Second, if magmas have initially low volatile contents and undergo some crystallisation and melt inclusion entrapment at depth, then such melts will be vapour-undersaturated.

Four of the five olivine-hosted inclusions that are volatile-undersaturated have $\mathrm{Fo}_{80}-\mathrm{Fo}_{88}, 1.3 \mathrm{wt} \%$ water and $\sim 1500-2160 \mathrm{ppm} \mathrm{CO}_{2}$, whereas the volatile-saturated inclusion has $\mathrm{Fo}_{71}, \sim 0.37 \mathrm{wt} \% \mathrm{H}_{2} \mathrm{O}$ and $271 \mathrm{ppm} \mathrm{CO}_{2}$. Thus, volatile saturation only appears to have occurred following a degree of crystallisation, reducing olivine Fo content. This observation is consistent with relatively low initial volatile 


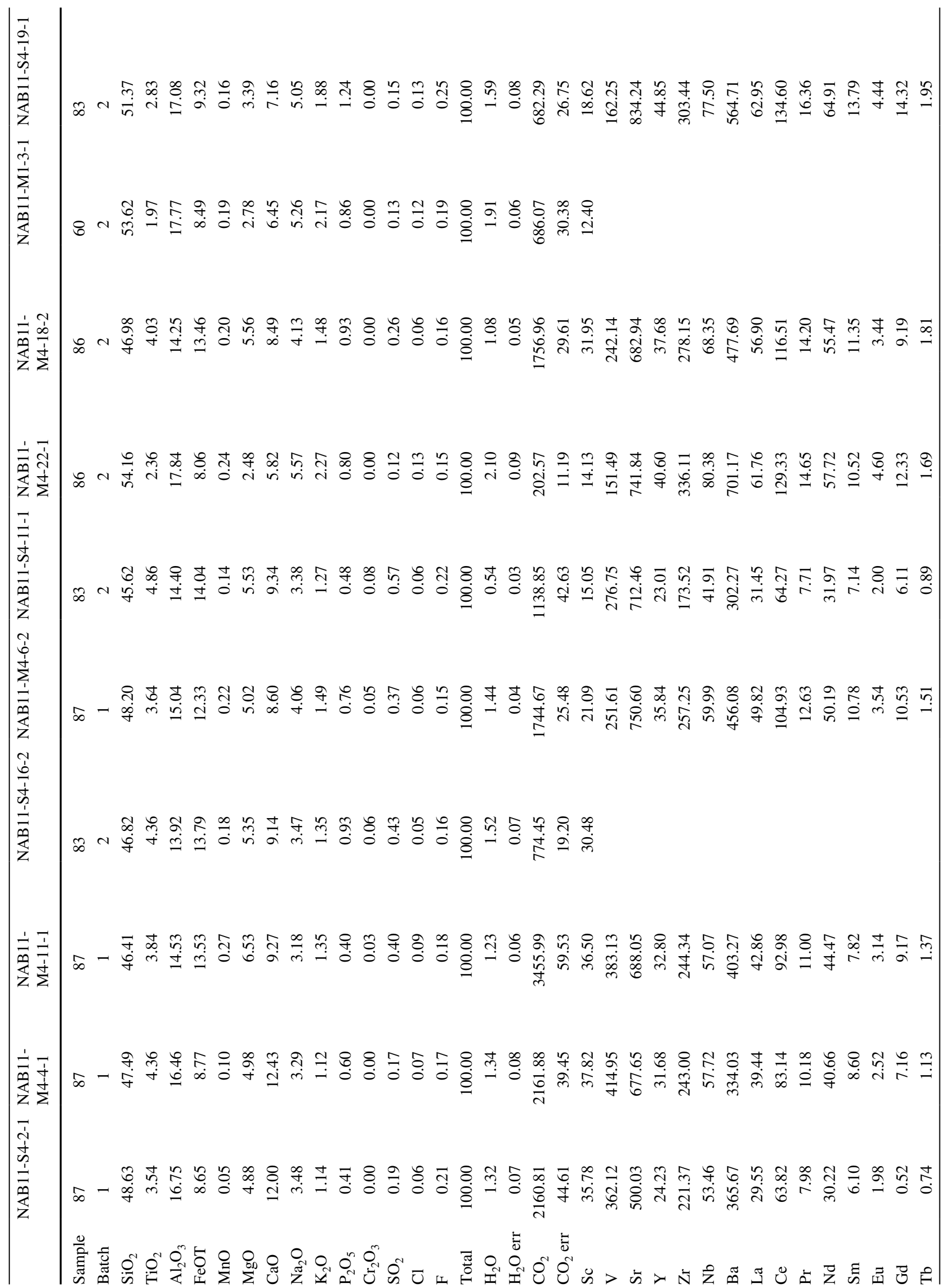




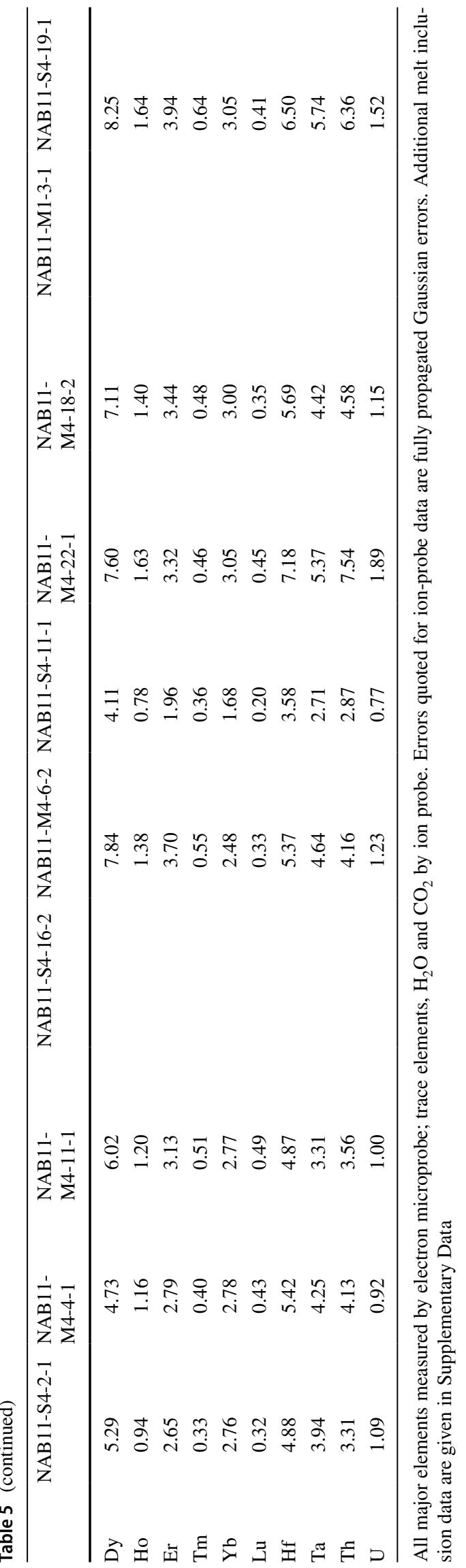

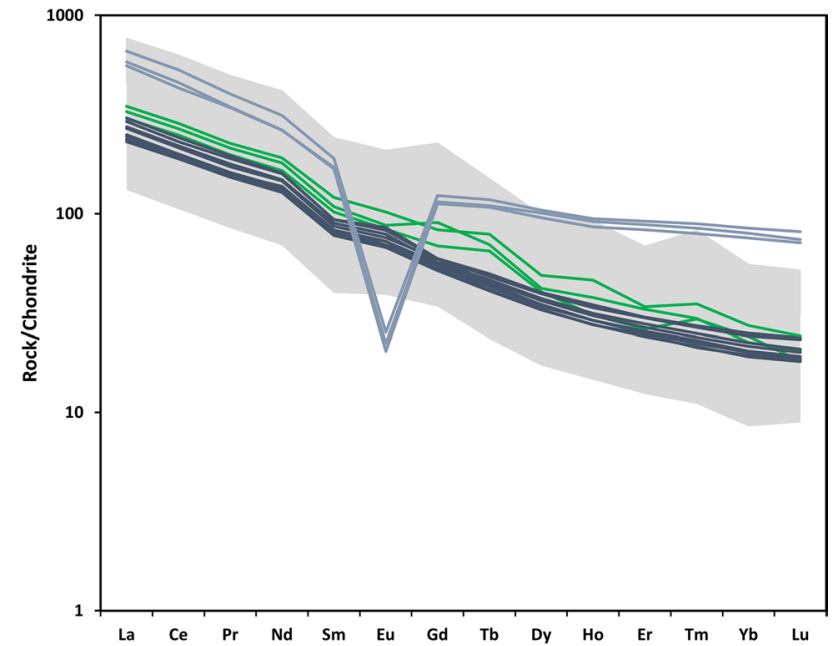

Fig. 8 Rare-earth element patterns for the Nabro melt inclusions. Grey area denotes the range of compositions spanned by the melt inclusions. Dark blue lines represent the 2011 whole rock, green lines are matrix glasses, and light blue are the ignimbrite whole rock. The REEs have been normalised to chondrite (McDonough and Sun 1995)

contents and some deep crystallisation and melt inclusion entrapment. Plagioclase anorthite content correlates positively with $\mathrm{S}$ and broadly negatively with both $\mathrm{H}_{2} \mathrm{O}$ and $\mathrm{Cl}$; although there is a group of inclusions with high An and low sulphur, these are dominantly from Batch 1 (An 70-80; S 500-1000 ppm). These trends might suggest that for most inclusions, appreciable $\mathrm{SO}_{2}$ degassing preceded the degassing of water and $\mathrm{Cl}$, consistent with relatively low initial $\mathrm{H}_{2} \mathrm{O} / \mathrm{S}$ ratio. However, early sulphide saturation may also play a role. We note that the inclusion containing a sulphide globule is hosted in a phenocryst core An $\sim 83$, in a Batch 2 sample.

\section{Thermometry and barometry from minerals and melt inclusions}

As shown in Fig. 7, there is a clear fractionation peak for $\mathrm{P}_{2} \mathrm{O}_{5}$ in our melt inclusion and whole-rock data. We have, therefore, applied an apatite saturation model (Harrison and Watson 1984; Pichavant et al. 1992) to estimate magma temperature for suitable inclusions. We also calculated pressure and temperature from the main mineral phases present using a variety of thermometers and barometers (Table 6). The models give temperatures ranging from 980 to $1146^{\circ} \mathrm{C}$ (with two outliers), but most inclusions indicate temperatures around $1080^{\circ} \mathrm{C}$ with $f \mathrm{O}_{2}$ between the QFM and NNO buffers. A touching pair of ilmenite and magnetite phenocrysts places $f \mathrm{O}_{2}$ of $\mathrm{NNO}+0.04$ (Ghiorso and Evans 2008) or NNO - 0.33 (Andersen and Lindsley 1988). Agreement between different thermometers is generally good (Table 6), with overlap between the melt inclusions and matrix glasses 

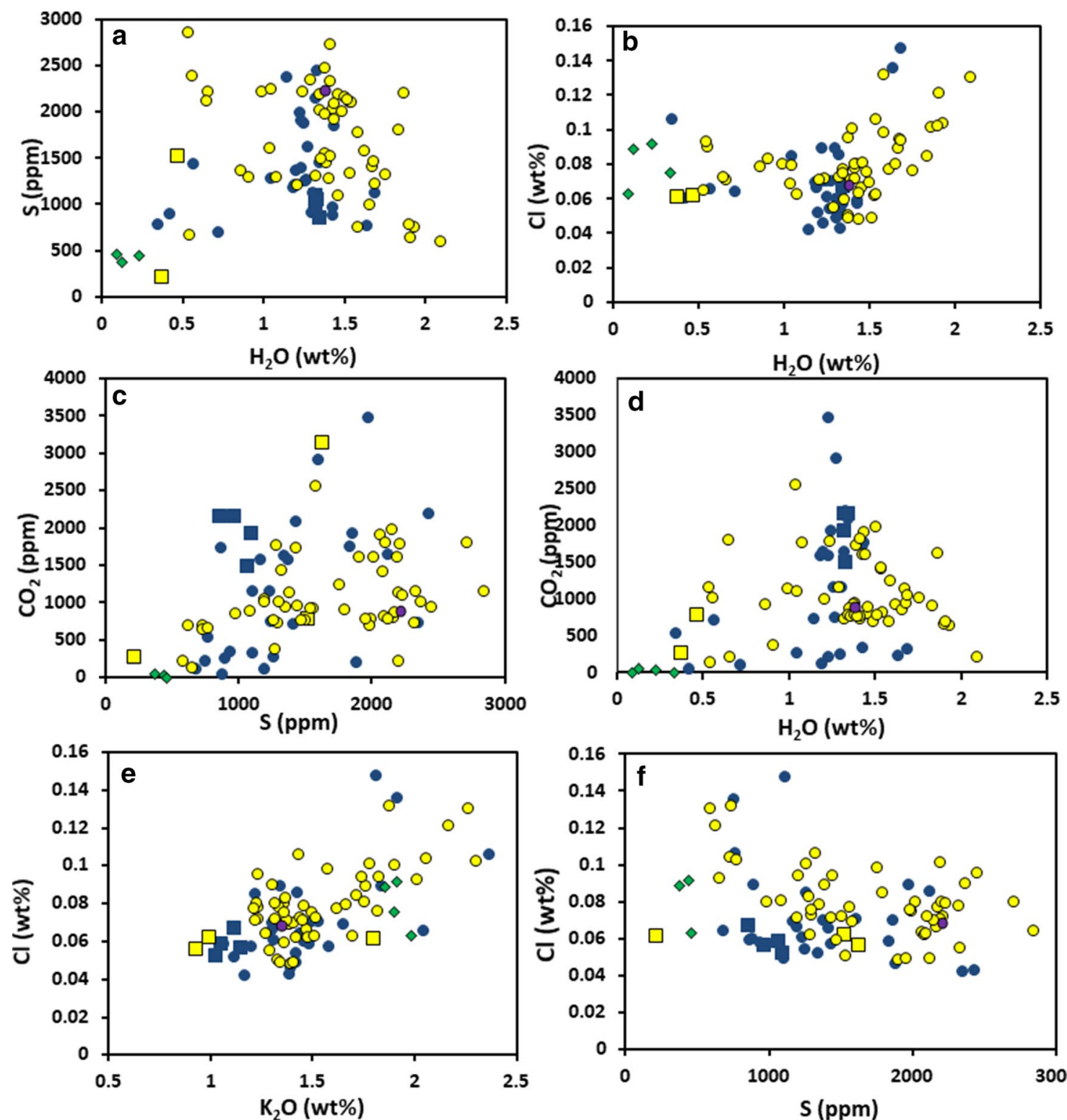

- Mls in olivine batch 1

$\square$ Mls in olivine batch 2

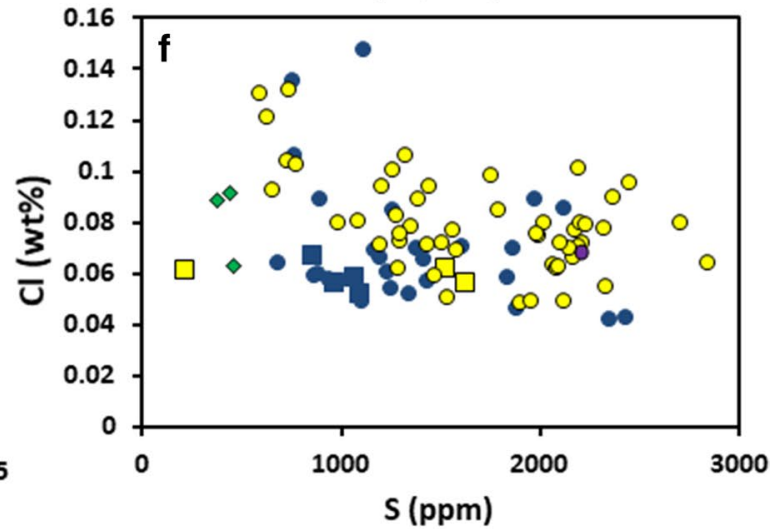

\section{$\diamond 2011$ basaltic tephra glass}

- Mls in plagioclase batch 1

- Ml including sulphide

O Mls in plagioclase batch 2

Fig. 9 Melt inclusion and glass volatile contents

(no statistically significant differences if the clinopyroxenemelt thermometer is excluded).

Melt inclusions that are demonstrably vapour-saturated allow the calculation of saturation pressures. Mineral saturation temperatures can be obtained from the chemistry of the coexisting melt inclusion and its host mineral, provided that subsequent chemical diffusion has not modified their chemistry. Using the temperatures modelled for each inclusion following Putirka (2005) and the $\mathrm{H}_{2} \mathrm{O}-\mathrm{CO}_{2}$ model of
Papale et al. (2006), we obtain saturation pressures for those melt inclusions considered to be vapour saturated, from 50 to $500 \mathrm{MPa}$. These pressures correlate with those obtained from the VolatileCalc model of Newman and Lowenstern (2002), but are mostly higher. The solubility model of Ghiorso and Gualda (2015) yields similar pressures to those of VolatileCalc, and we have chosen to use these values in the following discussion. We infer that volatile-undersaturated melt inclusions were trapped at pressures higher than 

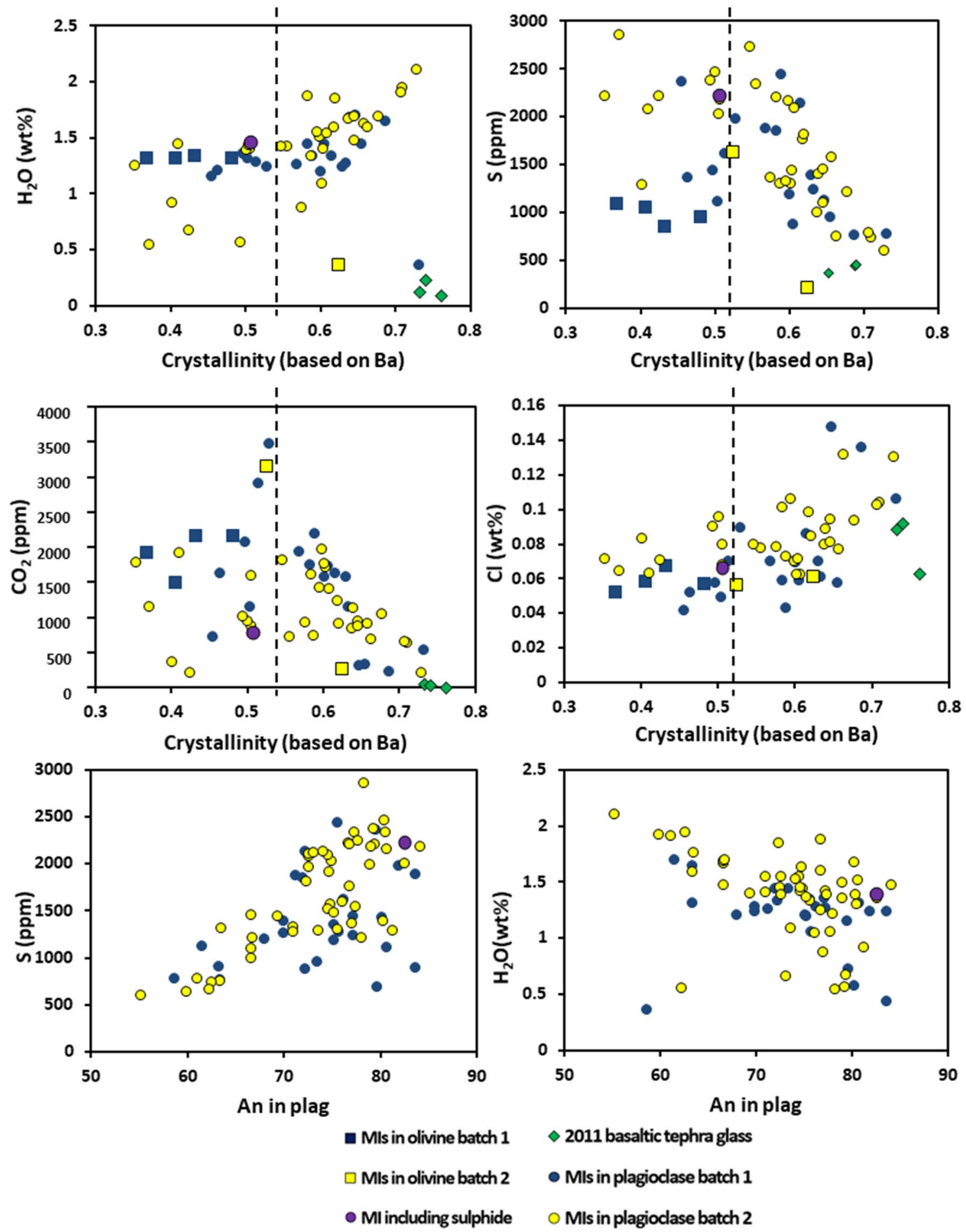

Fig. 10 Melt inclusion and glass volatile contents plotted against crystallinity (calculated from Ba content, as described in text) and plagioclase anorthite content. The black dashed line marks the point of vapour saturation based on the $\mathrm{CO}_{2}$-crystallinity plot

$\sim 500 \mathrm{MPa}$ (a full comparison of pressure and temperature models is provided in Supplementary Data).

In Fig. 11, we plot pressure, calculated from solubility models, against melt fraction for the vapour-saturated inclusions. This demonstrates that the inclusions have not undergone simple isobaric crystallisation, in which case crystallinity would increase at near-constant pressure. Crystallisation does tend to increase with decreasing pressure, although the data do not describe a simple decompression crystallisation trend, as there is some scatter at any given 
Table 6 Intrinsic variables calculated using a range of models (Andersen and Lindsley 1988; Beattie 1993; Ghiorso and Evans 2008; Harrison and Watson 1984; Papale et al. 2006; Putirka 2005; Putirka et al. 2003, 2007; Sisson and Grove 1993; Spencer and Lindsley 1981)

\begin{tabular}{lllll}
\hline Mineral & References & $T\left({ }^{\circ} \mathrm{C}\right)$ & $P(\mathrm{kbar})$ & $f \mathrm{O}_{2}$ \\
\hline Apatite & Harrison and Watson (1984) & $980-1020$ & \\
Olivine-melt (incl) & Beattie (1993) & $1066-1120$ & \\
& Putirka et al. (2007) & $1037-1084$ & \\
& Sisson and Grove (1993) & $992-1051$ & \\
Olivine-melt (matrix) & Beattie (1993) & $1120-1146$ & \\
& Putirka et al. (2007) & $1091-1126$ & \\
& Sisson and Grove (1993) & $1029-1059$ & \\
Plagioclase-melt (inclusions) & Putirka (2005) & $1063-1138$ & \\
Plagioclase-melt (matrix) & Putirka (2005) & $1098-1108$ & \\
Ilmenite-magnetite & Spencer and Lindsley (1981) & 1107 & & NNO -0.04 \\
& Andersen and Lindsley (1988) & 1002 & NNO-0.33 \\
& Ghiorso and Evans, (2008) & 1013 & & NNO+0.04 \\
Cpx-melt & Putirka et al. (2003) & $998-1104$ & $2.3-5.2$ & \\
Melt inclusion (volatile-saturated) & Papale et al. (2006) & & $0.2-4.6$ & \\
& Ghiorso and Gualda (2015) & & $0.2-2.6$ & \\
\hline
\end{tabular}

Oxide formulae recalculated according to Stormer (1983). Ilmenite-magnetite was calculated for a single touching pair. Crystal compositions were obtained either at the rim (for use with matrix compositions) or within 50 microns of the inclusion (melt inclusions)

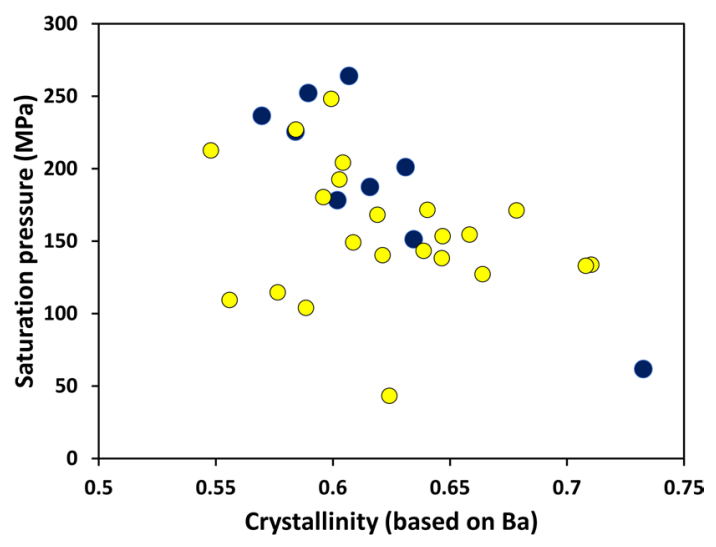

Fig. 11 Crystallinity (calculated from $\mathrm{Ba}$ as before) and volatile saturation pressure (from Ghiorso and Gualda 2015) for melt inclusions, whose chemistry suggests that they were vapour-saturated at the time of entrapment

pressure, notably at $200 \mathrm{MPa}$. In the next sections, we first return to the textural and chemical variations within the magmas, to explore the possibility that there are different evolutionary histories represented in the inclusions, and then model two potential processes that might explain the data.

\section{Evidence for multiple magma batches}

\section{Mineral evidence}

Apatite saturation occurred at lower temperatures than are given by some of the melt inclusions, and probably occurred at shallow levels. There are two populations of apatite phenocrysts-one that contains appreciable sulphur (up to
$500 \mathrm{ppm}$ ) and one that does not. Phenocrysts show some zoning in sulphur, where it is present, with rims being richer in sulphur than cores. Sulphur uptake by apatite is a function of $f \mathrm{O}_{2}$ as well as melt composition, and requires relatively oxidising conditions assuming that all $\mathrm{S}$ are incorporated as sulphate rather than sulphide (Boyce and Hervig 2008, 2009; Parat et al. 2008).

If we separate the two batches of magma based on our textural types, and plot the crystallinity of the melt against $\mathrm{P}_{2} \mathrm{O}_{5}$, we see that both batches were apatite-saturated at a late stage in their evolution, but large apatite phenocrysts are only found in Batch 2. This is further evidence of decompression crystallisation dominating the pre-eruption behaviour, as this would only increase temperature slightly due to latent heat release (Blundy et al. 2006).

As noted in "Petrography and mineralogy of 2011 samples", there are a wide range of phenocryst compositions, sizes, and zoning patterns in the samples. There are also xenocrysts of all the major phases, plus anorthoclase and orthopyroxene (both of which exhibit disequilibrium textures). While large, zoned phenocrysts are mainly found in Batch 2 of the samples, there are a few in Batch 1, which might suggest some mixing between the batches-consistent with the textural evidence in Fig. 4, and with the observation that both batches contain phenocrysts with apatite-saturated inclusions.

\section{Evidence from melt inclusion compositions}

Using the model of Liu et al. (2007), we calculated the sulphur content at sulphide saturation for our melt inclusions. According to this model, almost all the inclusions 


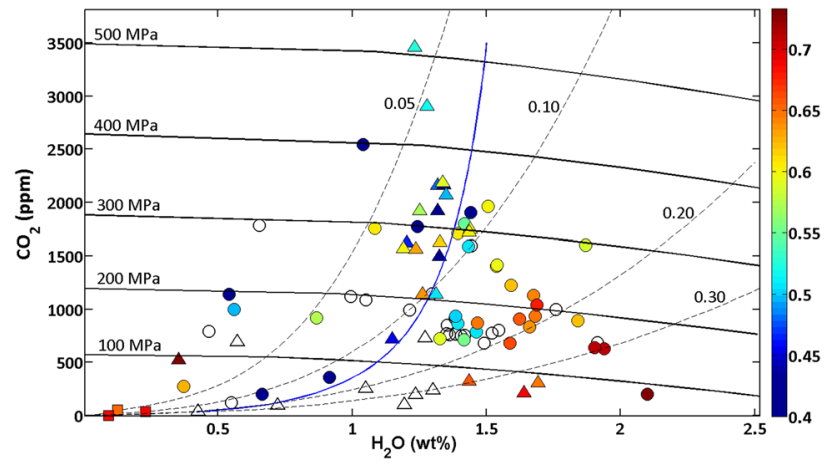

Fig. 12 Model evidence for isothermal degassing and isobaric crystallisation. Filled symbols are melt inclusions for which trace element data allowed calculation of crystal fraction (colour scale, based on Ba); open black symbols are other melt inclusions. Triangles are Batch 1; circles are Batch 2. Dashed black lines are vapour isopleths in mole fraction $\mathrm{H}_{2} \mathrm{O}$; and solid black lines are isobars (both isobars and isopleths calculated using VolatileCalc at $1080{ }^{\circ} \mathrm{C}$ ). The blue line is an isothermal degassing model from VolatileCalc at $1.5 \mathrm{wt} \% \mathrm{H}_{2} \mathrm{O}$, $1080{ }^{\circ} \mathrm{C}$

should be sulphide-saturated. There are also sulphide globules in the groundmass of some of the samples. We identify two modal populations of sulphur content in our inclusions. The Kruskal-Wallis test suggests that the two groups can be ascribed to different samples. As some of the samples were obtained from a section through the 2011 tephra deposit, it seems likely that the groups represent separate, but co-erupted, magma batches with different sulphur contents; plausibly a sulphide phase had separated from one and not the other in response to small variations in $\mathrm{fO}_{2}$. A sulphide phase (pyrrhotite) is present in a single melt inclusion in plagioclase. Melt inclusions analysed for major elements only in a single unzoned clinopyroxene phenocryst contain up to $3100 \mathrm{ppm} \mathrm{S}$.

Statistical analysis of the melt inclusion data by sample further suggests that there are different batches of magma involved in the eruption. The Kruskal-Wallis test successfully distinguishes between samples that exhibit crystalline groundmass (Batch 2), and those that are glassy (Batch 1). We, therefore, classified melt inclusions according to Batches 1 and 2 and used the Kolmogorov-Smirnov test to investigate the data. This showed that inclusions in Batch 1 (glassy) have lower $\mathrm{H}_{2} \mathrm{O}$ and $\mathrm{S}$ and higher $\mathrm{Mg} \#$ than those in Batch 2. However, both magmas appear to have reached apatite saturation. While there is considerable chemical overlap between the two batches, there are indications that Batch 2 underwent isobaric crystallisation in a storage region at $\sim 200 \mathrm{MPa}$, where it increased in water content and became saturated in S (note a few inclusions that are increasing in crystallinity at constant pressure in Fig. 11, and a larger number in Fig. 12), while Batch 1 ascended from depth and stalled only briefly in the shallow crust.

\section{Isothermal degassing vs. isobaric crystallisation}

Figure 12 shows the $\mathrm{H}_{2} \mathrm{O}$ vs. $\mathrm{CO}_{2}$ contents of the melt inclusions, along with isobars from VolatileCalc distinguished according to their crystallinity as calculated from $\mathrm{Ba}$. One melt inclusion in olivine with high $\mathrm{CO}_{2}(3150 \mathrm{ppm})$ and very low water $(0.2 \mathrm{wt} \%)$ is inferred to have lost water following entrapment (Bucholz et al. 2013). Melt inclusion volatile contents span a range of pressures (100-500 MPa) and vapour compositions. As noted above, the spread of the $\mathrm{CO}_{2}-\mathrm{H}_{2} \mathrm{O}$ data is not consistent with a simple closed or open degassing scenario; however, the data do offer insights into the sub-volcanic plumbing system, which evidently is vertically extensive. The data appear to define a broadly triangular region reminiscent of that described by Blundy and Cashman (2008, Fig. 31) for the case of a verticallyelongated plumbing system in which degassing and cooling occur concomitantly over a range of depths. The Blundy and Cashman (2008) model was developed for rhyolitic systems. We, therefore, derived a similar model, modified for basaltic melts (Fig. 12) to include both (1) isothermal degassing and (2) isobaric crystallisation. For (1), we assumed that degassing accompanied crystallisation during ascent, but that temperature remained constant at $1080{ }^{\circ} \mathrm{C}$ (i.e., we ignore contributions from latent heat release). For (2), we assumed that the magma was stored at a pressure of $200 \mathrm{MPa}(\sim 7 \mathrm{~km}$ depth) and that it was cooling and crystallising isobarically. The compositional dependence of volatile solubility in basalts introduces additional uncertainty into the model if we use the composition-sensitive model of Papale et al. (2006). Instead, for illustrative purposes, we used VolatileCalc for this, inputting the $\mathrm{SiO}_{2}$ for each inclusion separately and using average values for models.

The models in Fig. 12 suggest that Batch 1 of the magma ascended rapidly from depth and only degassed water at very shallow pressures $(<100 \mathrm{MPa})$, while Batch 2 (including the highly crystalline samples, red in Fig. 12) spent time in the shallow system $(\sim 200 \mathrm{MPa})$, increasing in $\mathrm{H}_{2} \mathrm{O}$ content due to isobaric crystallisation. This is supported by the evidence for apatite saturation and increasing water content at low $\mathrm{CO}_{2}$. There is evidently some crystal exchange between the batches, presumably due to crystal entrainment as one magma batch mingles with another during or shortly prior to eruption. The two textural batches are not clearly separated on any of the chemical plots that we present, and clearly have very similar sources. The evidence discussed earlier on relationships between $\mathrm{S}$, An, and crystallinity suggests that a sulphide phase had separated from Batch 2, but possibly not from Batch 1. The mismatch between texture and chemistry supports the idea, proposed by Annen et al. (2006), that chemistry is a magmatic character derived in the melt source region at depth, whereas texture is a character determined by the magma ascent path and eruption dynamics. This is also 


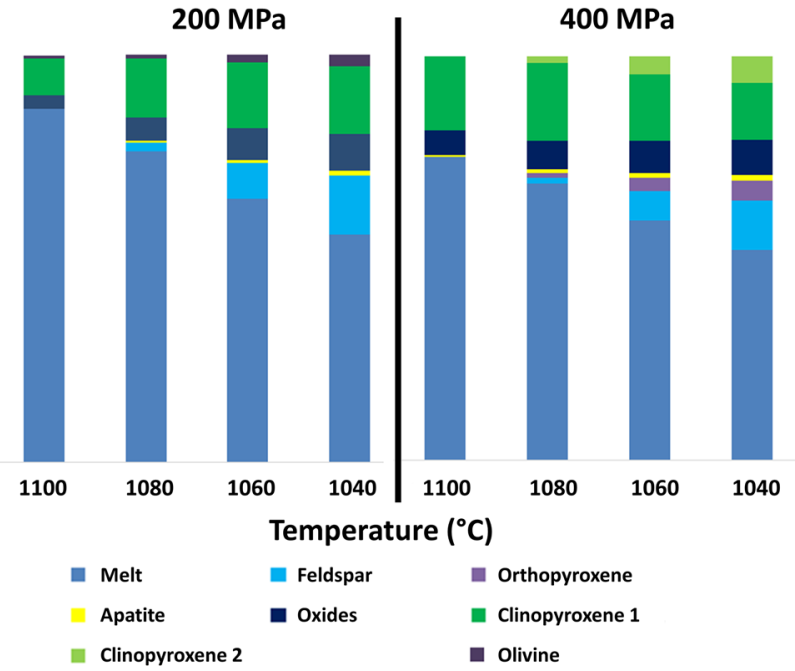

Fig. 13 Rhyolite-MELTS results for isobaric crystallisation of trachybasalt (Sample 61) at a $2 \mathrm{MPa}$ and b $400 \mathrm{MPa}$, at QFM and with $1.29 \mathrm{wt} \% \mathrm{H}_{2} \mathrm{O}$ dissolved in the melt

backed up by the absence of apatite in Batch 1. It is likely that the two batches with different ascent and storage histories mixed together shortly before or during eruption. Mixing of magmas with similar chemistry but different textures has been described previously from the 2012-13 eruption of Tolbachik, Kamchatka (Plechov et al. 2015). We prefer this explanation rather than one involving clast recycling at the vent because of the differences in modal mineralogy of the samples, the presence of inclusions that are more evolved than groundmass, and the absence of apatite in Batch 1.

\section{MELTS modelling}

We used the melt inclusion data above to perform MELTS modelling (Gualda et al. 2012), allowing us to integrate information from both the mineralogy and the melt inclusions. We modelled three separate processes, using a representative whole-rock composition (Sample 61: a trachybasaltic lava bomb from Batch 2-we also carried out models with Sample 12 from Batch 1, but the differences were minor) and $1.29 \mathrm{wt} \%$ dissolved $\mathrm{H}_{2} \mathrm{O}$ (consistent with the most primitive vapour-saturated inclusion). First, we modelled simple isobaric crystallisation at $400 \mathrm{MPa}$ (Fig. 13). The model confirms that clinopyroxene rather than olivine is the liquidus phase, with oxides appearing rapidly thereafter and plagioclase at $\sim 1088^{\circ} \mathrm{C}$. Olivine does not crystallise in this model, but apatite is stable at the lower temperature end. Orthopyroxene crystallises, although it is not observed in the natural samples with the exception of some rare relict xenocrysts. Second, we modelled isobaric crystallisation at $200 \mathrm{MPa}$. In this case, olivine is the liquidus phase, followed by clinopyroxene and spinel, with plagioclase appearing at $1085^{\circ} \mathrm{C}$. Interestingly, the phase assemblage at lower pressures is strongly influenced by $f \mathrm{O}_{2}$ : at QFM, olivine precedes plagioclase at pressures lower than $175 \mathrm{MPa}$, but at NNO, plagioclase always crystallises first. Orthopyroxene is stable only at high pressures (e.g., $400 \mathrm{MPa}$ ) and low temperatures, suggesting that the xenocrysts in the natural samples (see "Melt inclusion compositions") may be derived from a deep crustal reservoir.

Decompression crystallisation models similarly show clinopyroxene on the liquidus, with plagioclase and then olivine appearing at lower temperature. We tried a series of models from 600 to $100 \mathrm{MPa}$, some isothermal and others with decreasing temperature. In all of these models, $\mathrm{H}_{2} \mathrm{O}$ contents did not attain saturation levels (but the models ignore $\mathrm{CO}_{2}$, which would lead to earlier saturation). When pressure drops below $40 \mathrm{MPa}$, water degasses. In isothermal models, plagioclase is stable at $600 \mathrm{MPa}$ below $1090{ }^{\circ} \mathrm{C}$, which is consistent with the high saturation pressures obtained from the inclusions. Orthopyroxene destabilises at shallow pressures and lower temperatures, consistent with the textural evidence. Additional MELTS results are shown in the Supplementary Data.

MELTS modelling in alkaline rocks is challenging, and each of the models that we ran offers some insights into the magmatic system without producing results that match fully the data. Model results consistently suggest that clinopyroxene is the liquidus phase, but the order and onset of plagioclase and olivine crystallisation vary considerably, with both possible at high pressures, consistent with the melt inclusions. In some models, olivine crystallises considerably earlier than plagioclase, which might explain the high $\mathrm{CaO}$ and $\mathrm{Al}_{2} \mathrm{O}_{3}$ in the olivine inclusions relative to the plagioclase ones. The challenges of modelling alkaline rocks are discussed by Gleeson et al. (2017) and Rooney et al. (2012a). Rooney et al. (2012a) particularly note the problem that MELTS is not well calibrated for fluorapatite, something also evident in our results. Overall, however, modelling suggests that the magmas experienced a combination of isobaric cooling and degassing during decompression.

\section{Magma storage depths and plumbing system at Nabro}

Using a crustal density of $2780 \mathrm{~kg} \mathrm{~m}^{-3}$ (Makris and Ginzburg 1987), we calculate that most melt inclusions were trapped at 5-10 km depth (consistent with seismic data for the depth of a magma body; Hamlyn et al. 2014), but some may have been trapped close to the base of the crust, around $20 \mathrm{~km}$ depth (Hammond et al. 2011). The magma storage region is most likely composed of a series of sills and old eruptive products, evidenced by the presence of xenocrystic material in the magmas. The mineralogy, textures, and melt inclusion composition of the 2011 eruption suggests that, 


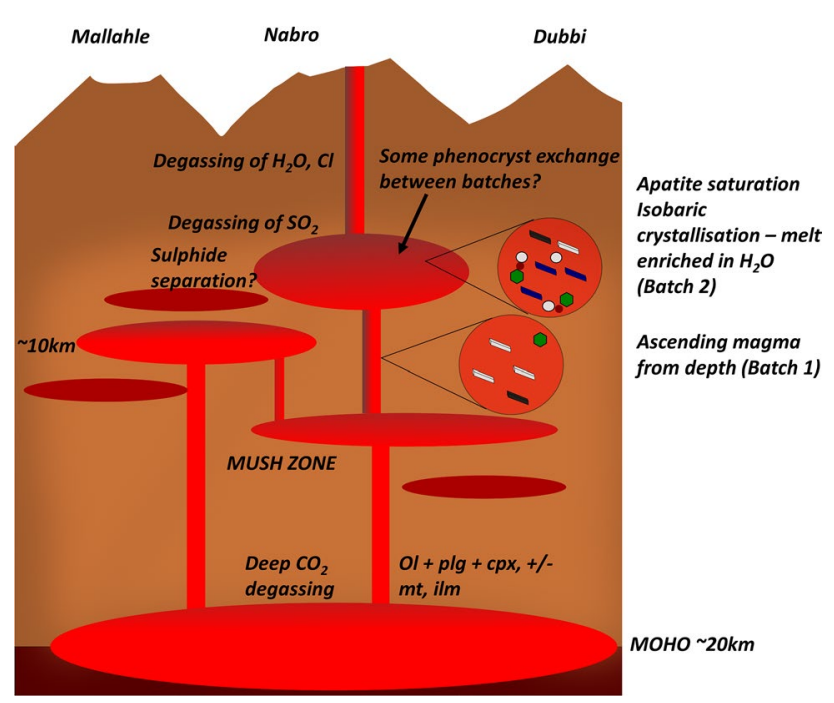

Fig. 14 Schematic cross section showing the main findings of this study. Melt lenses are red; mush zone is light brown; and gas is shown as grey circles within the melt lenses

based on textures, at least two batches of magma with different ascent and storage characteristics, but similar bulk compositions, were involved in the eruption.

The major and trace element composition of the inclusions suggests that their source region is most likely the same as that of older rocks found at Nabro and Dubbi volcanoes-indeed, older and more primitive basalts from the Edd Volcanic Field (Dubbi) provide a plausible "parental" composition for this magma (De Fino et al. 1978; Figs. 3, 14).

Alkali basalts have been shown experimentally to have higher volatile solubilities than other compositions due to weaker polymerisation (Dixon 1997; Dixon et al. 1997; Iacovino et al. 2013; Lesne et al. 2011b, c; Vetere et al. 2014). The Nabro lavas are higher in alkalis than other volcanic products in the Afar, probably due to a smaller initial melt fraction in the mantle source region, consistent also with their enrichment in REE and in LREE/HREE. The high solubility of $\mathrm{CO}_{2}$ in alkaline magmas supports the finding that some of the more primitive inclusions are volatile-undersaturated and represent the original volatile contents of the magma, which is relatively high in water $(\sim 1.3 \mathrm{wt} \%)$ for an intraplate basaltic magma. The most primitive of these melt inclusions was trapped at the base of the crust, suggesting a deep origin for their plagioclase and olivine hosts. It is likely that the magma was crystallising both these phases, plus clinopyroxene (positive correlation between $\mathrm{MgO}$ and $\mathrm{CaO} / \mathrm{Al}_{2} \mathrm{O}_{3}$ ), and an $\mathrm{Fe}-\mathrm{Ti}$ oxide phase (evidenced from $\mathrm{TiO}_{2}$ fractionation) as it rose through the lower crust. At shallow depths, the magma became saturated in apatite, and a sulphide phase separated. Apatite saturation appears to have preceded most water degassing: phosphorus behaves incompatibly in most inclusions, but does drop in those that are most rich in water. Water degassing occurred at relatively low pressures, $<1 \mathrm{kbar}$, but there are very few melt inclusions trapped at such shallow depths. Sulphur, however, decreases consistently with decreasing depth, suggesting that some $\mathrm{SO}_{2}$ was degassing throughout magma ascent. The melt inclusions can be modelled by a combination of isobaric crystallisation and closed-system degassing during ascent. It is likely that they represent two or more batches of melt sourced from a single and relatively homogeneous melt zone in the uppermost mantle $(\sim 20 \mathrm{~km}$ depth; Hammond et al. 2011), inferred on the basis of mineralogy and sulphur content. Melts ascending through the crust may crystallise through decompression, once water saturation is attained, or stall and crystallise by cooling.

Other work in the wider East African Rift, examining the Main Ethiopian Rift and Kenyan Rift zones, has reached similar conclusions about crustal mush zones (e.g., Rooney et al. 2012a, b; Gleeson et al. 2017). These papers indicate that volcanic systems in the Main Ethiopian Rift are characterised by vertically extensive magma plumbing that are likely compositionally zoned. Field et al. (2012b), however, working on another Afar volcano, posited a system of multiple sills to explain their data. Nabro, similarly, appears to have distinct batches of magma probably stored in sills, within a mush zone that likely consists of a wide range of compositions (evidenced by xenoliths in the erupted products, as well as by the presence of a wide range of compositions in older rocks).

Combining our observations, we suggest that the crust beneath Nabro and the other Bidu volcanoes comprise a vertically extensive mush zone, within which sit multiple intrusions of melt that have risen from the base of the crust and are in various stages of crystallisation and fluid saturation (Fig. 14). In the 2011 eruption, an intrusion of fresh trachybasalt (Batch 1) rose through the crust, and encountered an older body of trachybasaltic melt (Batch 2), which was remobilised and erupted, with some mingling between batches. This would explain the occurrence of different textural batches with similar bulk chemistry. It is plausible that gravitational instability in the mush is important in triggering eruption as suggested for eruptions of andesite magmas at Soufrière Hills volcano, Montserrat (Christopher et al. 2015). Mush destabilisation can also lead to copious release of $\mathrm{SO}_{2}$ gas previously stored at different levels, accounting for the large emission of $\mathrm{SO}_{2}$ during the 2011 eruption of Nabro relative to the sulphur content that could have been contained within the erupted magma (Bourassa et al. 2012).

Acknowledgements This work was supported by NERC urgency Grant NE/J012297/1 (Mechanisms and implications of the 2011 eruption of Nabro volcano, Eritrea). John Craven and Richard Hinton of the NERC 
Ion Microprobe Facility are thanked for assistance with the ion-probe analyses. Nick Marsh is thanked for help with XRF analyses. Jason Day is thanked for help with ICPMS measurements. AD was supported by a Fellowship from Leverhulme Trust and Newton Trust. JB acknowledges support from a Wolfson Research Merit Award. CO received additional support from the NERC Centre for Observation and Modelling of Earthquakes, volcanoes and Tectonics (COMET). The authors would like to thank Tyrone Rooney and an anonymous reviewer for comments that significantly improved the manuscript. We would also like to thank Mark Ghiorso for careful editorial handling.

Open Access This article is distributed under the terms of the Creative Commons Attribution 4.0 International License (http://creativecommons.org/licenses/by/4.0/), which permits unrestricted use, distribution, and reproduction in any medium, provided you give appropriate credit to the original author(s) and the source, provide a link to the Creative Commons license, and indicate if changes were made.

\section{References}

Andersen DJ, Lindsley DH (1988) Internally consistent solution models for $\mathrm{Fe}-\mathrm{Mg}-\mathrm{Mn}-\mathrm{Ti}$ oxides: $\mathrm{Fe}-\mathrm{Ti}$ oxides. Am Mineral 73(7-8):714-726

Annen C, Blundy J, Sparks R (2006) The genesis of intermediate and silicic magmas in deep crustal hot zones. J Petrol 47(3):505-539

Ayele A, Jacques E, Kassim M, Kidane T, Omar A, Tait S, Nercessian A, de Chabalier J-B, King G (2007) The volcano-seismic crisis in Afar, Ethiopia, starting September 2005. Earth Planet Sci Lett 255(1):177-187

Ayele A, Keir D, Ebinger C, Wright TJ, Stuart GW, Buck WR, Jacques E, Ogubazghi G, Sholan J, 2009. September 2005 mega-dike emplacement in the Manda-Harraro nascent oceanic rift (Afar depression). Geophys Res Lett, 36(20)

Baker DR (2008) The fidelity of melt inclusions as records of melt composition. Contrib Miner Petrol 156(3):377-395

Baker J, Chazot G, Menzies M, Thirlwall M (1998) Metasomatism of the shallow mantle beneath Yemen by the Afar plume-implications for mantle plumes, flood volcanism, and intraplate volcanism. Geology 26(5):431-434

Barberi F, Varet J (1977) Volcanism of Afar: Small-scale plate tectonics implications. Geol Soc Am Bull 88(9):1251-1266

Barberi F, Borsi S, Ferrara G, Marinelli G, Varet J (1970) Relations between tectonics and magmatology in the northern Danakil Depression (Ethiopia). Philosophical Transactions of the Royal Society of London A: mathematical. Phys Eng Sci 267(1181):293-311

Barberi F, Bonatti E, Marinelli G, Varet J (1974a) Transverse tectonics during the split of a continent: data from the Afar rift. Tectonophysics 23(1-2):17-29

Barberi F, Santacroce R, Varet J (1974b) Silicic peralkaline volcanic rocks of the Afar depression (Ethiopia). Bull Volcanol 38(2):755-790

Barrat J, Joron J, Taylor R, Fourcade S, Nesbitt R, Jahn B (2003) Geochemistry of basalts from Manda Hararo, Ethiopia: LREEdepleted basalts in Central Afar. Lithos 69(1):1-13

Beattie P (1993) Olivine-melt and orthopyroxene-melt equilibria. Contrib Miner Petrol 115(1):103-111

Blundy J, Cashman K (2008) Petrologic reconstruction of magmatic system variables and processes. Rev Mineral Geochem 69(1):179-239
Blundy J, Cashman K, Humphreys M (2006) Magma heating by decompression-driven crystallization beneath andesite volcanoes. Nature 443(7107):76

Bourassa AE, Robock A, Randel WJ, Deshler T, Rieger LA, Lloyd ND, Llewellyn ET, Degenstein DA (2012) Large volcanic aerosol load in the stratosphere linked to Asian monsoon transport. Science 337(6090):78-81

Boyce JW, Hervig RL (2008) Magmatic degassing histories from apatite volatile stratigraphy. Geology 36(1):63-66

Boyce JW, Hervig RL (2009) Apatite as a monitor of late-stage magmatic processes at Volcán Irazú, Costa Rica. Contrib Miner Petrol 157(2):135

Bucholz CE, Gaetani GA, Behn MD, Shimizu N (2013) Post-entrapment modification of volatiles and oxygen fugacity in olivinehosted melt inclusions. Earth Planet Sci Lett 374:145-155

Bureau H, Pineau F, Métrich N, Semet M, Javoy M (1998) A melt and fluid inclusion study of the gas phase at Piton de la Fournaise volcano (Réunion Island). Chem Geol 147(1):115-130

Cherniak D (2003) REE diffusion in feldspar. Chem Geol 193(1):25-41

Christopher T, Blundy J, Cashman K, Cole P, Edmonds M, Smith P, Sparks R, Stinton A, 2015. Crustal-scale degassing due to magma system destabilization and magma-gas decoupling at Soufrière Hills Volcano, Montserrat. Geochem Geophys Geosyst 16(9): 2797-2811

Civetta L, De Fino M, Gasparini P, Ghiara M, La Volpe L, Lirer L (1975) Structural meaning of east-central Afar volcanism (Ethiopia, TFAI). J Geol 83(3):363-373

Cottrell E, Spiegelman M, Langmuir C (2002) Consequences of diffusive reequilibration for the interpretation of melt inclusions. Geochem Geophys Geosyst 3(4):1-26

Courtillot V, Jaupart C, Manighetti I, Tapponnier P, Besse J (1999) On causal links between flood basalts and continental breakup. Earth Planet Sci Lett 166(3):177-195

Danyushevsky L, Plechov P, (2011) Petrolog3. Integrated software for modeling crystallization processes, $\mathrm{p} 12$

De Fino M, La Volpe L, Lirer L (1978) Geology and volcanology of the Edd-Bahar Assoli area (Ethiopia). Bull Volcanol 41(1):32-42

Dixon JE (1997) Degassing of alkalic basalts. Am Miner 82(3-4):368-378

Dixon JE, Clague DA (2001) Volatiles in basaltic glasses from Loihi Seamount, Hawaii: Evidence for a relatively dry plume component. J Petrol 42(3):627-654

Dixon JE, Clague DA, Wallace P, Poreda R (1997) Volatiles in alkalic basalts form the North Arch Volcanic Field, Hawaii: extensive degassing of deep submarine-erupted alkalic series lavas. J Petrol 38(7):911-939

Dixon JE, Leist L, Langmuir C, Schilling J-G (2002) Recycled dehydrated lithosphere observed in plume-influenced mid-ocean-ridge basalt. Nature 420(6914):385

Ebinger CJ, Sleep N (1998) Cenozoic magmatism throughout east Africa resulting from impact of a single plume. Nature 395(6704):788

Ebinger C, Ayele A, Keir D, Rowland J, Yirgu G, Wright T, Belachew M, Hamling I (2010) Length and timescales of rift faulting and magma intrusion: The Afar rifting cycle from 2005 to present. Annu Rev Earth Planet Sci 38:439-466

Edmonds M, Sides I, Swanson D, Werner C, Martin R, Mather T, Herd R, Jones R, Mead M, Sawyer G (2013) Magma storage, transport and degassing during the 2008-10 summit eruption at Kilauea Volcano, Hawai 'i. Geochim Cosmochim Acta 123:284-301

Ferguson DJ, Barnie TD, Pyle DM, Oppenheimer C, Yirgu G, Lewi E, Kidane T, Carn S, Hamling I (2010) Recent rift-related volcanism in Afar, Ethiopia. Earth Planet Sci Lett 292(3):409-418

Field L, Barnie T, Blundy J, Brooker RA, Keir D, Lewi E, Saunders K (2012a) Integrated field, satellite and petrological observations 
of the November 2010 eruption of Erta Ale. Bull Volcanol 74(10):2251-2271

Field L, Blundy J, Brooker R, Wright T, Yirgu G (2012b) Magma storage conditions beneath Dabbahu Volcano (Ethiopia) constrained by petrology, seismicity and satellite geodesy. Bull Volcanol 74(5):981-1004

Field L, Blundy J, Calvert A, Yirgu G (2013) Magmatic history of Dabbahu, a composite volcano in the Afar Rift, Ethiopia. Geol Soc Am Bull 125(1-2):128-147

Font L, Murton B, Roberts S, Tindle A (2007) Variations in melt productivity and melting conditions along SWIR (70 E-49 E): evidence from olivine-hosted and plagioclase-hosted melt inclusions. J Petrol 48(8):1471-1494

Furman T, Bryce J, Rooney T, Hanan B, Yirgu G, Ayalew D, 2006. Heads and tails: 30 million years of the Afar plume. Geol Soc Lond 259(1): 95-119 (special publications)

George R, Rogers N, Kelley S (1998) Earliest magmatism in Ethiopia: evidence for two mantle plumes in one flood basalt province. Geology 26(10):923-926

Ghiorso MS, Evans BW (2008) Thermodynamics of rhombohedral oxide solid solutions and a revision of the Fe-Ti twooxide geothermometer and oxygen-barometer. Am J Sci 308(9):957-1039

Ghiorso MS, Gualda GA (2015) $\mathrm{An}_{2} \mathrm{O}-\mathrm{CO}_{2}$ mixed fluid saturation model compatible with rhyolite-MELTS. Contrib Miner Petrol 169(6):53

Gleeson ML, Stock MJ, Pyle DM, Mather TA, Hutchison W, Yirgu G, Wade J (2017) Constraining magma storage conditions at a restless volcano in the Main Ethiopian Rift using phase equilibria models. J Volcanol Geoth Res 337:44-61

Goitom B, Oppenheimer C, Hammond JO, Grandin R, Barnie T, Donovan A, Ogubazghi G, Yohannes E, Kibrom G, Kendall J-M, 2015. First recorded eruption of Nabro volcano., Eritrea, 2011. Bull Volc, 77(10):1-21

Gualda GA, Ghiorso MS (2015) MELTS_Excel: a Microsoft Excel-based MELTS interface for research and teaching of magma properties and evolution. Geochem Geophys Geosyst 16(1):315-324

Gualda GA, Ghiorso MS, Lemons RV, Carley TL (2012) RhyoliteMELTS: a modified calibration of MELTS optimized for silicarich, fluid-bearing magmatic systems. J Petrol 53(5):875-890

Hagos M, Koeberl C, de Vries BvW (2016) The Quaternary volcanic rocks of the northern Afar Depression (northern Ethiopia): Perspectives on petrology, geochemistry, and tectonics. J Afr Earth Sc 117:29-47

Hamlyn JE, Keir D, Wright TJ, Neuberg JW, Goitom B, Hammond JO, Pagli C, Oppenheimer C, Kendall J, Grandin R (2014) Seismicity and subsidence following the 2011 Nabro eruption, Eritrea: Insights into the plumbing system of an off-rift volcano. J Geophys Res Solid Earth 119(11):8267-8282

Hammond J, Kendall JM, Stuart G, Keir D, Ebinger C, Ayele A, Belachew M (2011) The nature of the crust beneath the Afar triple junction: evidence from receiver functions. Geochem Geophys Geosyst. http://doi.org/10.1029/2011GC003738

Hammond J, Kendall J-M, Stuart G, Ebinger C, Bastow I, Keir D, Ayele A, Belachew M, Goitom B, Ogubazghi G (2013) Mantle upwelling and initiation of rift segmentation beneath the Afar Depression. Geology 41(6):635-638

Harrison TM, Watson EB (1984) The behavior of apatite during crustal anatexis: equilibrium and kinetic considerations. Geochim Cosmochim Acta 48(7):1467-1477

Hofmann C, Courtillot V, Feraud G, Rochette P (1997) Timing of the Ethiopian flood basalt event and implications for plume birth and global change. Nature 389(6653):838
Hudgins T, Mukasa S, Simon A, Moore G, Barifaijo E (2015) Melt inclusion evidence for $\mathrm{CO} 2$-rich melts beneath the western branch of the East African Rift: implications for long-term storage of volatiles in the deep lithospheric mantle. Contrib Miner Petrol 169(5):46

Hutchison R, Gass I (1971) Mafic and ultramafic inclusions associated with undersaturated basalt on Kod Ali Island, southern Red Sea. Contrib Miner Petrol 31(2):94-101

Iacovino K, Moore G, Roggensack K, Oppenheimer C, Kyle P (2013) $\mathrm{H}_{2} \mathrm{O}-\mathrm{CO}_{2}$ solubility in mafic alkaline magma: applications to volatile sources and degassing behavior at Erebus volcano, Antarctica. Contrib Miner Petrol 166(3):845-860

Keir D, Belachew M, Ebinger C, Kendall J-M, Hammond J, Stuart G, Ayele A, Rowland J (2011) Mapping the evolving strain field during continental breakup from crustal anisotropy in the Afar Depression. Nat Commun 2:285

Keir D, Bastow ID, Pagli C, Chambers EL (2013) The development of extension and magmatism in the Red Sea rift of Afar. Tectonophysics 607:98-114

Kent AJ (2008) Melt inclusions in basaltic and related volcanic rocks. Rev Mineral Geochem 69(1):273-331

Kuzmin D, Sobolev A (2003) Boundary layer effect on the composition of melt inclusions in olivine, EGS-AGU-EUG joint assembly, abstracts from the meeting held in Nice, France, 6-11 April 2003

Lahitte P, Gillot P-Y, Courtillot V (2003) Silicic central volcanoes as precursors to rift propagation: the Afar case. Earth Planet Sci Lett 207(1):103-116

Lebas MJ, Lemaitre RW, Streckeisen A, Zanettin B (1986) A chemical classification of volcanic-rocks based on the total alkali silica diagram. J Petrol 27(3):745-750

Le Voyer M, Kelley K, Cottrell E, Hauri E (2017) Heterogeneity in mantle carbon content from $\mathrm{CO}_{2}$-undersaturated basalts. Nat Commun. http://doi.org/10.1038/ncomms14062

Lesne P, Kohn SC, Blundy J, Witham F, Botcharnikov RE, Behrens $\mathrm{H}$ (2011a) Experimental simulation of closed-system degassing in the system basalt $-\mathrm{H}_{2} \mathrm{O}-\mathrm{CO}_{2}-\mathrm{S}-\mathrm{Cl}$. J Petrol 52(9):1737-1762

Lesne P, Scaillet B, Pichavant M, Beny J-M (2011b) The carbon dioxide solubility in alkali basalts: an experimental study. Contrib Miner Petrol 162(1):153-168

Lesne P, Scaillet B, Pichavant M, Iacono-Marziano G, Beny J-M (2011c) The $\mathrm{H}_{2} \mathrm{O}$ solubility of alkali basaltic melts: an experimental study. Contrib Miner Petrol 162(1):133-151

Liu Y, Samaha N-T, Baker DR (2007) Sulfur concentration at sulfide saturation (SCSS) in magmatic silicate melts. Geochim Cosmochim Acta 71(7):1783-1799

Longpré M-A, Stix J, Klügel A, Shimizu N (2017) Mantle to surface degassing of carbon-and sulphur-rich alkaline magma at El Hierro, Canary Islands. Earth Planet Sci Lett 460:268-280

Maclennan J (2008) Concurrent mixing and cooling of melts under Iceland. J Petrol 49(11):1931-1953

Makris J, Ginzburg A (1987) The Afar Depression: transition between continental rifting and sea-floor spreading. Tectonophysics 141(1-3):199-214

McDonough WF, Sun S-S (1995) The composition of the Earth. Chem Geol 120(3-4):223-253

Métrich N, Wallace PJ (2008) Volatile abundances in basaltic magmas and their degassing paths tracked by melt inclusions. Rev Mineral Geochem 69(1):363-402

Neave DA, Maclennan J, Hartley ME, Edmonds M, Thordarson T (2014) Crystal storage and transfer in basaltic systems: the Skuggafjöll eruption, Iceland. J Petrol 55(12):2311-2346

Newman S, Lowenstern JB (2002) VolatileCalc: a silicate melt- $\mathrm{H}_{2} \mathrm{O}-$ $\mathrm{CO}_{2}$ solution model written in Visual Basic for Excel. Comput Geosci 28(5):597-604 
Nielsen RL (2011) The effects of re-homogenization on plagioclase hosted melt inclusions. Geochem Geophys Geosyst. http://doi. org/10.1029/2011GC003822

Nielsen R, Crum J, Bourgeois R, Hascall K, Forsythe LM, Fisk MR, Christie DM (1995) Melt inclusions in high-An plagioclase from the Gorda Ridge: an example of the local diversity of MORB parent magmas. Contrib Miner Petrol 122(1):34-50

Norman MD, Garcia MO, Kamenetsky VS, Nielsen RL (2002) Olivine-hosted melt inclusions in Hawaiian picrites: equilibration, melting, and plume source characteristics. Chem Geol 183(1):143-168

Ottonello G, Piccardo G, Joron J, Treuil M (1978) Evolution of the upper mantle under the Assab Region (Ethiopia): suggestions from petrology and geochemistry of tectonitic ultramafic xenoliths and host basaltic lavas. Geol Rundsch 67(2):547-575

Papale P, Moretti R, Barbato D (2006) The compositional dependence of the saturation surface of $\mathrm{H}_{2} \mathrm{O}+\mathrm{CO}_{2}$ fluids in silicate melts. Chem Geol 229(1):78-95

Parat F, Holtz F, Feig S (2008) Pre-eruptive conditions of the Huerto andesite (Fish canyon system, San Juan volcanic field, Colorado): influence of volatiles $(\mathrm{C}-\mathrm{O}-\mathrm{H}-\mathrm{S})$ on phase equilibria and mineral composition. J Petrol 49(5):911-935

Pichavant M, Montel J-M, Richard LR (1992) Apatite solubility in peraluminous liquids: Experimental data and an extension of the Harrison-Watson model. Geochim Cosmochim Acta 56(10):3855-3861

Pik R, Marty B, Hilton D (2006) How many mantle plumes in Africa? The geochemical point of view. Chem Geol 226(3):100-114

Pik R, Marty B, Carignan J, Yirgu G, Ayalew T (2008) Timing of East African Rift development in southern Ethiopia: Implication for mantle plume activity and evolution of topography. Geology 36(2):167-170

Plechov P, Blundy J, Nekrylov N, Melekhova E, Shcherbakov V, Tikhonova MS (2015) Petrology and volatile content of magmas erupted from Tolbachik Volcano, Kamchatka, 2012-13. J Volcanol Geoth Res 307:182-199

Putirka KD (2005) Igneous thermometers and barometers based on plagioclase + liquid equilibria: Tests of some existing models and new calibrations. Am Miner 90(2-3):336-346

Putirka KD, Mikaelian H, Ryerson F, Shaw H (2003) New clinopyroxene-liquid thermobarometers for mafic, evolved, and volatilebearing lava compositions, with applications to lavas from Tibet and the Snake River Plain, Idaho. Am Miner 88(10):1542-1554

Putirka KD, Perfit M, Ryerson F, Jackson MG (2007) Ambient and excess mantle temperatures, olivine thermometry, and active vs. passive upwelling. Chem Geol 241(3):177-206

Rooney TO, Hart WK, Hall CM, Ayalew D, Ghiorso MS, Hidalgo P, Yirgu G (2012a) Peralkaline magma evolution and the tephra record in the Ethiopian Rift. Contrib Miner Petrol 164(3):407-426
Rooney TO, Herzberg C, Bastow ID (2012b) Elevated mantle temperature beneath East Africa. Geology 40(1):27-30

Rosenthal A, Hauri E, Hirschmann M (2015) Experimental determination of $\mathrm{C}, \mathrm{F}$, and $\mathrm{H}$ partitioning between mantle minerals and carbonated basalt, $\mathrm{CO}_{2} / \mathrm{Ba}$ and $\mathrm{CO}_{2} / \mathrm{Nb}$ systematics of partial melting, and the $\mathrm{CO} 2$ contents of basaltic source regions. Earth Planetary Science Letters 412:77-87

Rowe MC, Kent AJ, Nielsen RL (2007) Determination of sulfur speciation and oxidation state of olivine hosted melt inclusions. Chem Geol 236(3):303-322

Schilling J (1973) Afar mantle plume: rare earth evidence. Nature 242(114):2-5

Shorttle O, Maclennan J, Piotrowski AM (2013) Geochemical provincialism in the Iceland plume. Geochim Cosmochim Acta 122:363-397

Sides I, Edmonds M, Maclennan J, Houghton B, Swanson D, SteeleMacInnis M (2014) Magma mixing and high fountaining during the 1959 Kīlauea Iki eruption, Hawai ‘i. Earth Planet Sci Lett 400:102-112

Sisson T, Grove T (1993) Experimental investigations of the role of $\mathrm{H}$ $2 \mathrm{O}$ in calc-alkaline differentiation and subduction zone magmatism. Contrib Mineral Petrol 113(2):143-166

Spencer KJ, Lindsley DH (1981) A solution model for coexisting irontitanium oxides. Am Mineral 66(11-12):1189-1201

Stormer JC (1983) The effects of recalculation on estimates of temperature and oxygen fugacity from analyses of multicomponent iron-titanium oxides. Am Miner 68(5-6):586-594

Theys N, Campion R, Clarisse L, van Gent J, Dils B, Corradini S, Merucci L, Coheur PF, Van Roozendael M, Hurtmans D, Clerbaux C, Tait S, Ferrucci F (2013) Volcanic $\mathrm{SO}_{2}$ fluxes derived from satellite data: a survey using OMI, GOME-2, IASI and MODIS. Atmos Chem Phys (ACP). https://doi.org/10.5194/ acp-13-5945-2013

Ukstins IA, Renne PR, Wolfenden E, Baker J, Ayalew D, Menzies M (2002) Matching conjugate volcanic rifted margins: $40 \mathrm{Ar} / 39 \mathrm{Ar}$ chrono-stratigraphy of pre-and syn-rift bimodal flood volcanism in Ethiopia and Yemen. Earth Planet Sci Lett 198(3):289-306

Vetere F, Holtz F, Behrens H, Botcharnikov RE, Fanara S (2014) The effect of alkalis and polymerization on the solubility of $\mathrm{H}_{2} \mathrm{O}$ and $\mathrm{CO}_{2}$ in alkali-rich silicate melts. Contrib Miner Petrol 167(5): 1014

Wallace PJ (1998) Water and partial melting in mantle plumes: Inferences from the dissolved $\mathrm{H} 2 \mathrm{O}$ concentrations of Hawaiian basaltic magmas. Geophys Res Lett 25(19):3639-3642

Wiart P, Oppenheimer C (2005) Large magnitude silicic volcanism in north Afar: the Nabro Volcanic Range and Ma'alalta volcano. Bull Volcanol 67(2):99-115

Winpenny B, Maclennan J (2011) A partial record of mixing of mantle melts preserved in Icelandic phenocrysts. J Petrol 52(9):1791-1812 